\title{
FROM INDIVIDUAL JUDGE TO JUDICIAL BUREAUCRACY: THE EMERGENCE OF JUDICIAL COUNCILS AND THE CHANGING NATURE OF JUDICIAL ACCOUNTABILITY IN COURT ADMINISTRATION
}

\author{
TIN BUNJEVAC*
}

\section{INTRODUCTION}

Over the last 20 years, courts in Australia and many developed countries have experienced an exponential increase in the number and complexity of cases coming before them, which was also accompanied by increasing public expectations regarding the cost, timeliness, quality and accessibility of justice. ${ }^{1}$ Judges have found themselves under increasing pressure from politicians, prosecutors, lawyers, the media and other stakeholders to share the burden of cost-cutting in the public sector and deliver more justice in less time and for less money. ${ }^{2}$ There is implicit recognition that governments have all but exhausted their regulatory tool kit for combating delay in the justice system: record numbers of judges have been appointed, new tribunals have been established and successive legislative reforms have been implemented in an attempt to simplify the rules of evidence and legal procedure, and encourage alternative ways of resolving disputes. ${ }^{3}$ And yet, despite all of these efforts, the challenges of complexity, cost and delay in litigation have only continued to grow, threatening

* Dr Tin Bunjevac is a lecturer of court governance and management at the Sir Zelman Cowen Centre's Courts and Tribunals Academy and Victoria Law School. He would like to thank Professors Kathy Laster and Anne Wallace for their helpful comments on an earlier draft of this paper.

1 See generally Stephen Parker, Courts and the Public (Australian Institute of Judicial Administration, 1998); Marco Fabri, Philip M Langbroek and Hélène Pauliat (eds), The Administration of Justice in Europe: Towards the Development of Quality Standards (Research Institute on Judicial Systems, National Research Council, 2003); Tania Sourdin, 'The Timeliness Project: Background Report' (Report, Australian Centre for Justice Innovation, 2013); Tin Bunjevac, 'Court Governance in Context: Beyond Independence’ (2011) 4(1) International Journal for Court Administration 35.

2 Marco Fabri and Philip M Langbroek, 'Developing a Public Administration Perspective on Judicial Systems in Europe' in Marco Fabri and Philip M Langbroek (eds), The Challenge of Change for Judicial Systems: Developing a Public Administration Perspective (IOS Press, 2000) 1.

3 See, eg, Lord Woolf, 'Access to Justice: Final Report to the Lord Chancellor on the Civil Justice System in England and Wales' (Report, Lord Chancellors Department, 1996); A A S Zuckerman, Civil Justice in Crisis: Comparative Perspectives of Civil Procedure (Oxford University Press, 1999); Victorian Law Reform Commission, Civil Justice Review, Report No 14 (2008). See Tania Sourdin and Naomi Burstyner, 'Justice Delayed is Justice Denied' (2014) 4 Victoria University Law and Justice Journal 46, 48-9. 
a crisis of confidence that could potentially undermine the independence and legitimacy of the judiciary as well. ${ }^{4}$

While many judges have been acutely aware of the emerging challenges in their environment, they found it difficult to initiate meaningful reforms, for a variety of reasons. Traditionally, the executive government had been in charge of court administration, which left judges poorly equipped to manage the courts and 'unmotivated to do anything strategic about it' ${ }^{5}$ Furthermore, because of their specific professional training and experience, judges had little inclination to work together as part of a court bureaucracy and assiduously sought to protect their individual independence, even in the performance of basic administrative tasks. Over time, however, all of these factors contributed to the sense of a deepening 'organizational "atrophy", ${ }^{6}$ which fostered a growing realisation among judicial leaders and policymakers that structural organisational change was one of the few remaining options left to transform the courts into modern, thriving and, above all, responsive institutions. ${ }^{7}$ This article analyses the recent structural reforms of court governance that have led to the establishment of judicial councils in Australia, Canada, Ireland, the Netherlands, Sweden, the United Kingdom ('UK'), the United States ('US') and other countries, which have been implemented largely in response to the identified challenges. ${ }^{8}$ It will be argued that the transfer of responsibility for court administration from the executive government to an independent judicial council has the potential not only to safeguard judicial independence, but also to improve court performance, achieve greater customer focus in the court system and bring about an institutional renewal of the judiciary as a whole.

The article begins with an analysis of the arguments in favour of greater judicial control of court administration, before moving on to examine two traditional policy challenges of judge-controlled court systems that have been identified in the literature. The first challenge is to develop an effective system of judicial administrative accountability that does not undermine judicial independence, and the second is to devise a policy framework for a judicial council and courts that is effective, relevant and accountable. In response to the first challenge, it will be argued that the introduction of formal and transparent administrative hierarchies within the judiciary is both justified and necessary, in

4 Sir Gerard Brennan, 'Key Issues in Judicial Administration' (1997) 6 Journal of Judicial Administration 138, 139. For a recent analysis of these issues, see Annette Marfording and Ann Eyland, 'Civil Litigation in New South Wales: Empirical and Analytical Comparisons with Germany’ (Research Paper No 201028, UNSW Law, 15 July 2010).

5 Peter A Sallmann, 'Courts' Governance: A Thorn in the Crown of Judicial Independence?' (2007) 16 Journal of Judicial Administration 139, 141-2.

6 Bunjevac, 'Court Governance in Context: Beyond Indepence', above n 1, 35.

7 Gar Yein Ng, 'A Discipline of Judicial Governance?' (2011) 7(1) Utrecht Law Review 102. Ng argues that all of the identified trends call for a new scientific discipline of judicial governance. For a Victorian perspective on these issues, see Courts' Strategic Directions Working Group, 'Courts Strategic Directions Project (Report, Victoria, 2 September 2004) ('Courts Strategic Directions Project').

8 See, eg, Tin Bunjevac, 'Court Governance: The Challenge of Change' (2011) 20 Journal of Judicial Administration 201. 
order to improve court performance, enhance the social legitimacy of the courts and reinforce judicial independence.

The analysis of the second challenge will then be used to outline the basic institutional contours of a judicial council, which is based on a synthesis of Australian and international best practices. In particular, the analysis will be used to identify the key aims, competencies and other essential terms of reference for a modern judicial council that is relevant and effective, and also to clarify its relationship with the courts, executive government and other stakeholders. It will be argued that the transfer of responsibility for court administration from the executive government to the judicial council has the potential not only to safeguard judicial independence, but also to improve the quality of justice and assist judges adopt new forms of accountability in court administration.

\section{JUDICIAL CONTROL OF COURT ADMINISTRATION}

The arguments in favour of greater judicial control of court administration have been traditionally advanced with reference to the doctrine of the separation of powers and the need to protect the collective independence of the judiciary. Justice Robert Nicholson argues that the very existence of judicial independence 'cannot be separated from adequate and proper judicial administration', because the latter requires that both policymaking and policy administration are controlled by the judiciary. ${ }^{9}$ A similar view was expressed by former South Australian Chief Justice Leonard King, who regarded it as the 'essential principle ... that the judiciary has the constitutional responsibility for the administration of justice', and therefore should also be responsible for the administration of the courts. ${ }^{10}$ In the Chief Justice's view, the establishment of the South Australian Judicial Council in 1993 represented the clearest expression of that principle in practice, because the South Australian judiciary had since assumed full responsibility for court administration in that State. ${ }^{11}$

The arguments for greater judicial control of court administration also find support in the international 'soft law' jurisprudence on judicial independence, such as the Montreal Universal Declaration on the Independence of Justice, which expressly provides that the responsibility for court administration should vest in the judiciary. ${ }^{12}$ However, there is no general agreement on this issue in public international law, constitutional theory or the academic literature. For example, the United Nations Basic Principles on the Independence of the Judiciary address certain aspects of court administration in general terms, but

9 Justice R D Nicholson, 'Judicial Independence and Accountability: Can They Co-exist?' (1993) 67 Australian Law Journal 404, 422.

10 Chief Justice King, 'A Judiciary-based State Courts Administration - The South Australian Experience' (1993) 3 Journal of Judicial Administration 133, 136. See also Chief Justice L J King, 'Minimum Standards of Judicial Independence' (1984) 58 Australian Law Journal 340.

11 King, 'A Judiciary-based State Courts Administration', above n 10. See also Sir Guy Green, 'The Rationale and Some Aspects of Judicial Independence' (1985) 59 Australian Law Journal 135, 143-8.

12 First World Conference on the Independence of Justice, Montreal Declaration, Universal Declaration on the Independence of Justice (10 June 1983) art 2.04. 
ultimately leave it to the discretion of the member states to provide the 'adequate resources to enable the judiciary to properly perform its functions'. ${ }^{13}$ The Bangalore Principles of Judicial Conduct also express the need to protect the 'institutional and operational independence of the judiciary', but stop short of endorsing a specific model of court administration. ${ }^{14}$ The same general theme is reiterated in the Commonwealth Principles on the Three Branches of Government ('Latimer House Principles'), which call for 'adequate resources' to be provided to the judiciary to allow it to operate effectively and independently. ${ }^{15}$

Church and Sallmann make a useful distinction between the adjudicatory and administrative independence of the judiciary in this context. ${ }^{16}$ They point out that there is disagreement in the literature as to whether judicial control over court administration is sensu stricto necessary to ensure the impartial decision-making by individual judges. ${ }^{17} \mathrm{~A}$ study by Gee et al recently examined a wealth of constitutional literature from the UK and other countries and concluded that "there is no settled relationship between structures and behaviour - or what is sometimes called "de jure" and "de facto" independence' ${ }^{18}$ They pointed out that judges in the UK traditionally behaved impartially, even in the absence of formal structures that were in theory deemed necessary to ensure the administrative independence of the judiciary. ${ }^{19}$ Nevertheless, the authors noted that there was an increasing awareness of the need to ensure that there were adequate formal mechanisms available to promote collective judicial independence in the UK. ${ }^{20}$

While there is disagreement in the literature about the impact of formal governance structures on judicial independence, it is difficult to deny that the executive control of court administration impacts court performance, which - in turn - can potentially also affect judicial independence. ${ }^{21}$ The interdependence in the relationship between court performance and judicial independence was highlighted by Baar et al in an important study of the 'Alternative Models of Court Administration', which was commissioned by the Canadian Judicial

13 Seventh United Nations Congress on the Prevention of Crime and the Treatment of Offenders, Milan, 26 August - 6 September 1985: Report Prepared by the Secretariat, UN Doc A/CONF.121/22/Rev1 (1986) 59 , art 7.

14 Judicial Group on Strengthening Judicial Integrity, 'The Bangalore Principles of Judicial Conduct' (Revised 25-26 November 2002) para 1.5.

15 The Commonwealth Secretariat, 'Commonwealth (Latimer House) Principles on the Three Branches of Government' (April 2004) principle IV(c).

16 Thomas W Church and Peter A Sallmann, Governing Australia's Courts (Australian Institute of Judicial Administration, 1991) 7.

17 See, eg, Justice R E McGarvie, 'The Foundations of Judicial Independence in a Modern Democracy' (1991) 1 Journal of Judicial Administration 3, 6. Justice McGarvie argues that judicial independence requires only 'independence in making decisions in court cases between litigants'. This approach has been characterised as 'minimalist'. See also Sallmann, above n 5, 142.

18 Graham Gee et al, The Politics of Judicial Independence in the UK's Changing Constitution (Cambridge University Press, 2015) 12. For a US perspective, see also Gordon Bermant and Russell R Wheeler, 'Federal Judges and the Judicial Branch: Their Independence and Accountability' (1995) 46 Mercer Law Review 835, 852-3. The authors note that 'compared to the matter of decisional independence, the claim for branch independence has a much more tenuous grounding in constitutional history'.

19 Gee et al, above n $18,13$.

20 Ibid.

21 Sallmann, above n 5, 141. 
Council ('CJC') in 2006. ${ }^{22}$ The authors pointed out that judges in the executive system had little fiscal and operational authority, which made it difficult for them to operate outside of broader government directives and, therefore, potentially represented a 'significant threat to the independence of our judiciary'. ${ }^{23}$ An Australian court management study commissioned by the Australian Institute for Judicial Administration ('AIJA study') further illustrated this problem in practice by highlighting certain budgetary patterns in the state courts that were managed by the executive government. Alford, Gustavson and Williams found it unusual that the executive government could - '[a]t unpredictable intervals' - transfer funds from the courts' agreed annual budget to other areas within the Department of Justice, which made it very difficult for the courts to plan ahead and achieve annual outputs mandated by the Treasury. ${ }^{24}$

The AIJA study also examined the internal division of administrative responsibilities between judges and court staff and concluded that the executive control of court operations was "problematic both for judicial independence on the one hand and for the efficiency and effectiveness of the courts on the other' ${ }^{25}$ Alford, Gustavson and Williams explain that the internal management separation between the judiciary and court administration was considered to be sub-optimal in the management literature and was also a potential cause of organisational delay, because more steps were involved in the internal decision-making processes. ${ }^{26}$ They pointed out that modern principles of organisational design assume a far greater degree of alignment between 'authority' and 'responsibility' within an organisation, so that those individuals who have responsibility to achieve certain outcomes should also have authority over the necessary resources to achieve those outcomes. ${ }^{27}$ The authors concluded that this was clearly not the case in most Australian state courts, where judges had the responsibility to improve court performance, while having insufficient authority over the courts' administrative and financial resources. ${ }^{28}$

The findings of the AIJA study did not come as a surprise to the judiciary, as they had firsthand experience of the problems impacting the court operations. In 2004, the Chief Judges of the Victorian courts prepared a report that painted a grim picture of the state of the Victorian judicature and put forward compelling arguments in favour of greater judicial control of court administration. ${ }^{29}$ They highlighted a series of newly emerging internal and external challenges that were

22 Carl Baar et al, 'Alternative Models of Court Administration' (Final Report, Canadian Judicial Council, September 2006).

23 Ibid 15. See also Justice T H Smith, 'Court Governance and the Executive Model' (Paper presented at the Judicial Conference of Australia Colloquium, Canberra, 6-8 October 2006) 6-7, 32-3. Justice Smith points out that the Victorian courts constantly had to compete for funding with other agencies within the Department of Justice's 'departmental behemoth'.

24 John Alford, Royston Gustavson and Philip Williams, The Governance of Australia's Courts: A Managerial Perspective (Australian Institute of Judicial Administration, 2004) vii.

25 Ibid 85.

26 Ibid 23.

27 Ibid 20, 85-6.

28 Ibid 85-6.

29 Courts Strategic Directions Project, above n 7, 51-63. 
impacting on the functioning of the courts. ${ }^{30}$ These challenges included ongoing political and budgetary pressures, unprecedented delays and backlogs, the growing litigiousness of society, greater complexity of the law, higher service and quality expectations, and constant demands that the courts deliver more justice in less time and for less money. ${ }^{31} \mathrm{~A}$ careful analysis of the issues outlined in the document suggests that the focus of the court governance debate in Victoria had shifted somewhat from the need to protect judicial independence from the executive government alone, towards an urgent need to protect the courts and judges from multiple internal and external threats to judicial independence, integrity and relevance. ${ }^{32}$

The Victorian Chief Judges were also unanimous in their assessment that the key obstacle to responding to the identified challenges was the executive system of court administration. ${ }^{33}$ In particular, they contended that judges were lacking the managerial authority to strategically plan the operations of their courts. At the same time, the executive officers in charge of court operations were not best placed to make effective decisions about competing court priorities, because they were embedded in an external government bureaucracy that was physically separated from the courts and had its own organisational demands and priorities. ${ }^{34}$ According to Church and Sallmann, this situation perpetuated a farreaching interpersonal divide between judges and court administration, to the point that even the courts' own Court Executive Officers ('CEOs') were routinely not invited to meetings that discussed essential court processes, because judges regarded them as 'executive officials' rather than 'court people' ${ }^{35}$

Following the publication of the Courts' Strategic Directions document, it became clear even to government policymakers that the courts simply could not cope with surging demands. ${ }^{36}$ By 2010, the Government had exhausted practically all of its options, having implemented extensive procedural reforms and appointed many new judges. ${ }^{37}$ However, despite record levels of funding flowing into the court system, the Victorian courts' performance continued to lag far behind all other Australian jurisdictions. ${ }^{38}$ The magnitude of the problem is illustrated in Table 1 below, which shows an exponential increase in case

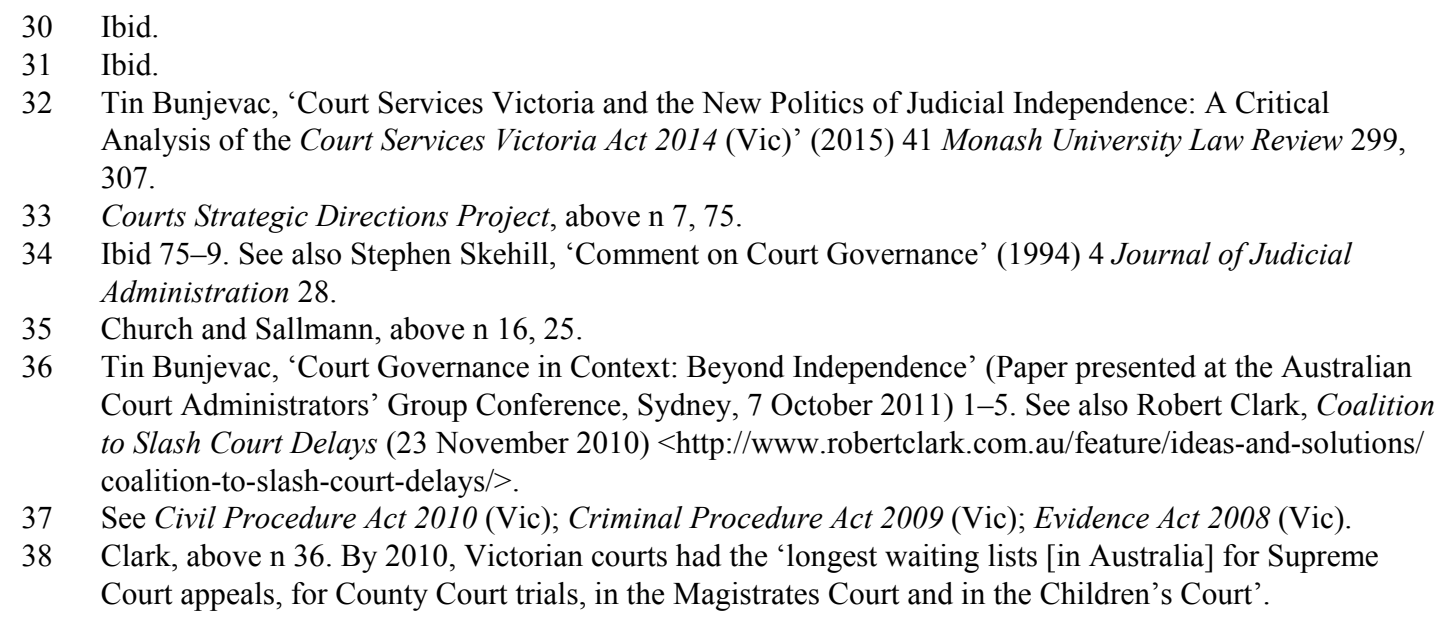

37 See Civil Procedure Act 2010 (Vic); Criminal Procedure Act 2009 (Vic); Evidence Act 2008 (Vic).

38 Clark, above n 36. By 2010, Victorian courts had the 'longest waiting lists [in Australia] for Supreme Court appeals, for County Court trials, in the Magistrates Court and in the Children's Court'. 
lodgements and pending cases backlogs that occurred in the five years following the publication of the Courts' Strategic Directions document. ${ }^{39}$

Figure 1: Victorian Courts' Workload 2005-09

\section{COURT WORKLOAD - ALL COURTS}

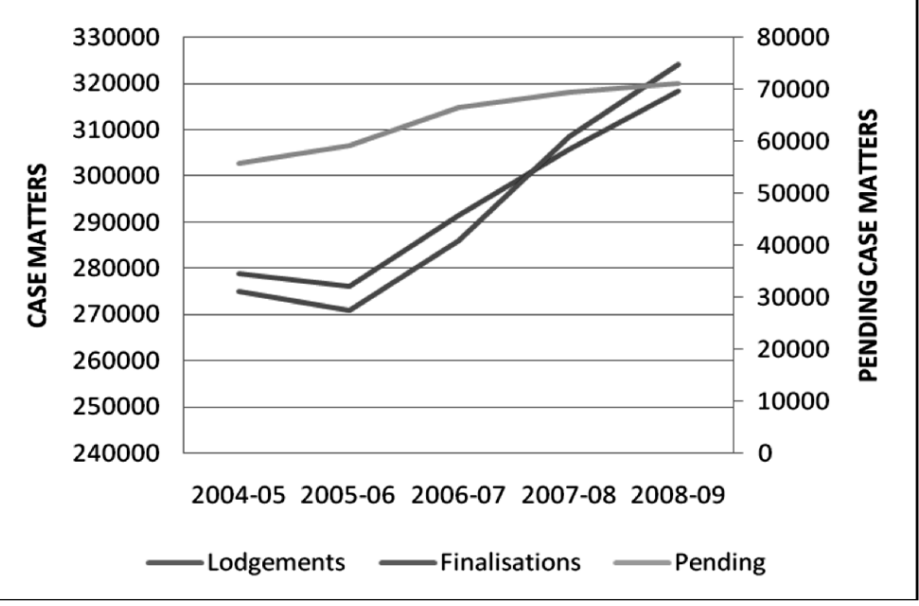

This image is reproduced with the permission of the Department of Justice.

The Victorian data shown in Table 1 is striking and deserves fuller explanation. It shows that the number of pending cases continued to rise despite marked improvement in case finalisations between 2005 and 2009 (which was primarily achieved through new judicial appointments). ${ }^{40}$ Under normal conditions, an increase in the rate of case finalisations would reduce the pending cases backlog, but this did not occur in Victoria, where the backlog continued to rise. In the circumstances, the continuing rise in the pending cases backlog was a sign that the courts' resources were still insufficient to meet the increasing demand, or - alternatively - that they were simply not being used in an optimal way. ${ }^{41}$ This was certainly the conclusion reached by the incoming Victorian Liberal Nationals Coalition government, which promised to 'slash court delays

39 Department of Justice (Vic), 'Managing Court Demand' (Policy Proposal, December 2009) 19.

40 Notably, the data in Table 1 does not capture the full story, as it does not take into account the increases in volume in the previous five-year period. For example, in 2000-01 there were 92294 criminal cases initiated in the Magistrates' Court of Victoria compared to 167359 in 2008-09, an increase of over 80 per cent. See The Council of Magistrates, 'Annual Report 1 July 2000 - 30 June 2001' (Magistrates' Court of Victoria, 2002) 23; The Council of Magistrates, '2008-09 Anual Report' (Magistrates' Court of Victoria, 2010) 22.

41 Department of Justice (Vic), above n 39, 4. By 2008-09, Victoria's 'backlog indicator' had reached 22.3 per cent, which was by far the worst performance in Australia: Steering Committee for the Review of Government Service Provision, 'Report on Government Services 2010: Court Administration' (Productivity Commission, 2010) 7.27. The 'backlog indicator' is the percentage of lodgements pending completion that are older than a threshold time period. For Supreme Courts and District/County Courts, the report sets the national standard of 'no more than 10 per cent of lodgments pending completion are to be more than 12 months old'. 
with a comprehensive package of reforms', and establish an independent judicial council to be run by the judges themselves. ${ }^{42}$

\section{A Problems Associated with Judicial Control of Court Administration}

The analysis so far suggests that a judge-controlled system of court administration would likely lead to greater institutional independence of the judiciary and improvements to court performance, through better organisational alignment between authority and responsibility within the courts. ${ }^{43}$ Alford, Gustavson and Williams also pointed out that greater involvement of judges in court administration would lead to an increase in judicial interest in, and responsibility for, the management affairs of the courts. ${ }^{44}$ However, an increase in judicial interest and responsibility for court administration does not automatically translate into a better court system or more effective court organisation. This point was illustrated by former Queensland District Court Judge Michael Forde, who analysed a range of court performance data from the District Courts of New South Wales, Queensland and South Australia in the late 1990s. ${ }^{45}$ His study concluded that the South Australian courts were less productive than the Queensland courts, despite the fact that they were managed by the judiciary and the Queensland courts were managed by the executive government. ${ }^{46}$

While the South Australian court system has been the subject of 'much favourable comment and attention ... both within Australia and internationally', ${ }^{47}$ the example given by Judge Forde clearly demonstrates the potential dangers facing any jurisdiction seeking to transfer the responsibility for court administration from the executive government to the judiciary. Indeed, experiences from other jurisdictions show that problems of organisational misalignment can persist in judge-controlled court systems as well. For example, this issue can potentially arise if judges fail to engage with the rest of the court administration, due to ongoing reliance on their traditional judicial administrative arrangements, ${ }^{48}$ or where a new court administration authority merely replicates the management patterns that were established under the executive model. ${ }^{49} \mathrm{At}$

42 Clark, above n 36.

43 Alford, Gustavson and Williams, above n 24, 85-6.

44 Ibid 89-92.

45 Michael William Forde, What Model of Court Governance Would Optimize the Expeditious Delivery of Justice, Judicial Independence and the Accountability of Queensland's Court System? (Master of Public Sector Management Dissertation, Griffith University, 2000).

46 Ibid 59-61. Notably, Judge Forde also found that the South Australian courts were the most expensive courts to litigate in across the three jurisdictions under review: at 54-6. See also Laurie Glanfield, 'Governing the Courts - Issues of Governance Beyond Structure' (Speech delivered at the $18^{\text {th }}$ Australian Institute of Judicial Administration Annual Conference, Darwin, 14-16 July 2000) 4. According to Glanfield, in 1997-98 South Australia ranked last on the timeliness criteria published in the Report on Government Services.

47 Peter A Sallmann and Tim Smith, 'Constitutionalism and Managerial Effectiveness: Revisiting Australian Courts' Governance' in Australian Courts: Serving Democracy and its Publics (Australasian Institute of Judicial Administration, 2013) 265, 271. Sallmann, above n 5, 143.

48 Wim Voermans and Pim Albers, 'Councils for the Judiciary in EU Countries' (Report, European Commission for the Efficiency of Justice ('CEPEJ'), March 2003) 37, 112.

Baar et al, above $n$ 22, 102-3. 
the more extreme end of the spectrum, a poorly-designed institutional framework can potentially turn the judicial council into a 'structure of intra-judicial oppression, run in the name of "judicial independence", as was recently pointed out by Bobek and Kosar in a damning assessment of the newly-established Eastern European judicial councils. ${ }^{50}$

The picture that emerges shows that the transfer of responsibility for court administration to the judiciary is far more complex than a simple handover from the Department of Justice to an independent judicial council, because the character of court governance is fundamentally different than that under the executive model. In the new organisational paradigm, judges are responsible not only for their traditional administrative arrangements that focus on the legal procedure; they also have assumed the responsibility to act as managers and policymakers for the administrative, financial and human resources operations of the courts. Undoubtedly, these issues have important ramifications for the structure of court governance and coordination of the judicial and administrative processes across the entire court system.

Against this background, it becomes clear that the primary challenge for judges and policymakers lies in devising the appropriate institutional and policy frameworks that are capable of sustaining an effective system of judge-controlled court administration. As Millar and Baar put it in their seminal work Judicial Administration in Canada, judge-controlled court systems 'must evolve from the present non-systems'. ${ }^{11}$ Drawing upon their extensive experience of the North American court system reforms, Millar and Baar highlight two common policy challenges of judge-controlled systems of court administration. The first challenge is for the judiciary to develop an effective system of internal administrative accountability, while the second is to establish a supporting judicial council that is relevant, responsive and effective in practice. ${ }^{52}$

\section{POLICY CHALLENGE ONE: DEVELOPING AN EFFECTIVE SYSTEM OF JUDICIAL ADMINISTRATIVE ACCOUNTABILITY}

The first policy challenge identified by Millar and Baar lies at the heart of modern court administration: how can the judiciary in a mature democracy develop an effective system of administrative accountability that is capable of responding to the identified challenges without undermining judicial independence ${ }^{53}$ This article contends that the answer to this question lies in devising a policy framework of court governance that would help

50 Michal Bobek and David Kosař, 'Global Solutions, Local Damages: A Critical Study in Judicial Councils in Central and Eastern Europe’ (2014) 15 German Law Journal 1257, 1288.

51 Perry S Millar and Carl Baar, Judicial Administration in Canada (McGill-Queen's University Press, 1981) 67-71.

52 Ibid.

53 See generally Andrew Le Sueur, 'Developing Mechanisms for Judicial Accountability in the UK' (2004) 24 Legal Studies 73, 74; Carlo Guarnieri and Patrizia Pederzoli, The Power of Judges: A Comparative Study of Courts and Judges (Oxford University Press, 2002) 156-60. 
promote greater administrative corporatisation of the judiciary and allow the courts to successfully transition from organisations of professionals to professional organisations..$^{54}$ According to Langbroek, the difficulty of achieving that transition can be attributed to the fact that the judicial working culture is characterised by individual autonomy and administrative passivity, which is frequently justified by reference to the constitutional doctrine of the separation of powers. ${ }^{55}$ However, while that working culture may be regarded as a strong attribute when it comes to protecting judicial independence, Langbroek sees it as a serious obstacle to achieving future organisational development of the courts, because it is impossible to implement administrative reforms in any large organisation without a more robust system of administrative accountability and discipline. ${ }^{56}$ Langbroek also points out that the courts operate within the broader framework of duty in the public sector, where the work of judges and public servants is 'intertwined' ${ }^{57}$ As a result, it is evident that the process of organisational development in the courts cannot be successfully carried out by the court staff alone, without active judicial participation and leadership in that process. ${ }^{58}$ This leads Langbroek to conclude that the concept of judicial accountability in court administration requires 'new elaboration' ${ }^{59}$

\section{A Reconceptualising Judicial Accountability and Independence in Court Administration}

The 'dynamic tension' ${ }^{60}$ between judicial administrative accountability and independence is a central theme of academic literature on court governance, because it has important implications for the constitutional and organisational aspects of court administration. ${ }^{61}$ The constitutional aspect arises when the development of an internal system of administrative accountability starts posing a threat to judicial independence. ${ }^{62}$ A classic formulation of this argument is given by Shetreet, who warns that the creation of 'hierarchical patterns' within the

54 Wim Voermans and Pim Albers, 'Geintegreerde Rechtbanken: Het Vervolg, Evaluatierapport Herziening Rechtlijke Organisatie (Onderdeel II)' (Government of the Netherlands, 1994) 70, 90-1.

55 Philip M Langbroek, 'Quality Management and Autonomy for Court-Organisations' (Paper, EGPA Studygroup on Management and Delivery of Justice, 2001) 10.

56 Ibid.

57 Ibid 9-10.

58 Ibid 10. See also Philip M Langbroek, 'Two Cases of Changing the Judiciary and the Judicial Administration: The Netherlands and Guatemala' (Paper presented at the World Bank Conference on Empowerment, Security and Opportunity through Law and Justice, St Petersburg, Russia, 8-11 July 2001) 10.

59 Langbroek, 'Quality Management and Autonomy', above n 55, 10.

60 Shimon Shetreet, 'Judicial Independence: New Conceptual Dimensions and Contemporary Challenges' in Shimon Shetreet and Jules Deschênes (eds), Judicial Independence: The Contemporary Debate (Martinus Nijhoff Publishers, 1985) 590, 639.

61 See generally Le Sueur, above n 53; Nicholson, above n 9; Gee et al, above n 18; Amy B Atchison, Lawrence Tobe Liebert and Denise K Russell, 'Judicial Independence and Judicial Accountability: A Selected Bibliography’ (1999) 72 Southern California Law Review 723.

62 Justice R E McGarvie, 'Judicial Responsibility for the Operation of the Court System' (1989) 63 Australian Law Journal 79, 87. 
judiciary might have a 'chilling effect on judicial independence' ${ }^{63}$ For example, this issue could potentially arise if a senior judge improperly assigns a junior judge to a remote location to influence his or her decision-making, ${ }^{64}$ or a dominant chief justice improperly uses the power to assign cases to ensure results he or she personally approves. ${ }^{65}$

At the same time, however, the development of an internal system of judicial accountability is also concerned with the need to maintain public confidence in the judiciary and improve court performance. ${ }^{66}$ According to Justice Richard McGarvie and Professor Ian Scott, when it comes to court performance, a clear distinction must be made between judicial independence and 'judicial individualism', which they regard as a serious obstacle to effective court management. ${ }^{67}$ They separately argue that judicial independence may only be invoked by a judge who is improperly pressured by others in the process of deciding a dispute, but not by a judge who simply refuses to participate in court administration. ${ }^{68}$ This point is also made by Professor Kate Malleson, who sees no inherent conflict between judicial accountability and independence in court administration if a more qualified definition of judicial independence is adopted, that of 'freedom from improper interference which would undermine party impartiality' ${ }^{69}$

Malleson argues that it is party impartiality that must be protected and that collective judicial independence has no justification that is separate from its relationship with party impartiality. ${ }^{70}$ Importantly, she also argues that the

63 Shetreet, above n 60, 639, 655.

64 Gee et al, above n 18, 13.

65 Neil Andrews, 'Vinegar Free? Sir Garfield Barwick's Recipe for Judicial Salad' (1996) 3 Canberra Law Review 175, 189. The author makes reference to Sir Garfield Barwick's controversial practices during his time as the Chief Justice of the High Court of Australia. Arguably, the problem could potentially also arise where a judicial council imposes financial penalties on judges who fail to meet agreed "production targets'. See Richard Mohr and Francesco Contini, 'Judicial Evaluation in Context: Principles, Practices and Promise in Nine European Countries' (2007) 1(2) European Journal of Legal Studies 254, 271-2. The authors give the example of the Spanish Judicial Council, which offered bonuses and imposed financial penalties on judges based on their productivity.

66 Nicholson, above n 9, 424. See also Francesco Contini and Richard Mohr, 'Reconciling Independence and Accountability in Judicial Systems' (2007) 3(2) Utrecht Law Review 26; Chief Justice Murray Gleeson, 'Public Confidence in the Judiciary' (2002) 76 Australian Law Journal 558.

67 McGarvie, 'Judicial Responsibility for the Operation of the Court System', above n 62, 87, citing I R Scott, 'The Future of Judicial Administration' in Garrie J Moloney (ed), Constitutional and Administrative Responsibilities for the Administration of Justice: The Partnership of Judiciary and Executive (Australian Institute of Judicial Administration, 1985) 73, 82. See also Lord Woolf, 'Judicial Independence Not Judicial Isolation' in Christopher Campbell-Holt (ed), The Pursuit of Justice (Oxford University Press, 2008) 161; Ernest C Friesen, Edward C Gallas and Nesta M Gallas, Managing the Courts (Bobbs-Merrill, 1971) 133-4.

68 McGarvie, 'Judicial Responsibility for the Operation of the Court System', above n 62, 87.

69 Kate Malleson, The New Judiciary: The Effects of Expansion and Activism (Ashgate, 1999) 71 (emphasis added). See also Kate Malleson, 'Judicial Training and Performance Appraisal: The Problem of Judicial Independence' (1997) 60 The Modern Law Review 655, 663-6; Mauro Cappelletti, “"Who Watches the Watchmen?” A Comparative Study on Judicial Responsibility' (1983) 31 American Journal of Comparative Law 1, 15-16. According to Cappelletti, 'independence, far from being an end in itself, is but an instrumental value, the goal of which is to safeguard another value - ... the impartiality of the judge'.

70 Malleson, The New Judiciary, above n 69, 63. 
application of the more qualified definition of judicial independence would allow for the introduction of new forms of administrative accountability by the judiciary, which are needed to improve court performance, maintain public confidence in the courts, and counter the judiciary's growing influence in public policy. ${ }^{71}$ Examples of the 'soft accountability' mechanisms proposed by Malleson include greater internal organisational transparency, more diverse representation, a more transparent judicial appointments process, greater openness to academic scrutiny and even the introduction of a formal system of performance appraisals. $^{72}$

Contini and Mohr seek to reconcile the dynamic tension between judicial independence and accountability in court administration by introducing the concept of 'cooperative accountability', which is similar to Malleson's concept of 'soft accountability' in that it calls for greater administrative transparency within the judiciary. ${ }^{73}$ They argue that the relationship between judicial independence and accountability is not a 'zero sum game', whereby an increase in judicial accountability automatically leads to a reduction in judicial independence or vice versa. ${ }^{74}$ For them accountability is like Boven's broader 'social relation' contract ${ }^{75}$ that involves a two-way channel of communication between the courts and their stakeholders. ${ }^{76}$ Therefore, an accountable judiciary should strive to establish the appropriate processes and strategies that explain the internal culture, values and workings of the judicial organisation to its stakeholders. ${ }^{77}$ Secondly, the courts must also provide appropriate organisational strategies and mechanisms to demonstrate that members of the organisation act in accordance with those values. ${ }^{78}$ If conceived in this way, Mohr and Contini conclude, accountability in judicial systems is not limited to promoting court performance, but also serves to reinforce the essential values that the courts seek to uphold, such as the rule of law, equality, independence and impartiality. ${ }^{79}$

\section{B Administrative Accountability and Court Performance}

The relationship between judicial administrative accountability and court performance is also dynamic and must be placed into the broader social context of the administration of justice as an essential public service. Gar Yein $\mathrm{Ng}$ classified the court environment as a 'professional bureaucracy', based on the organisational typology developed by Professor Henry Mintzberg. ${ }^{80}$ According to

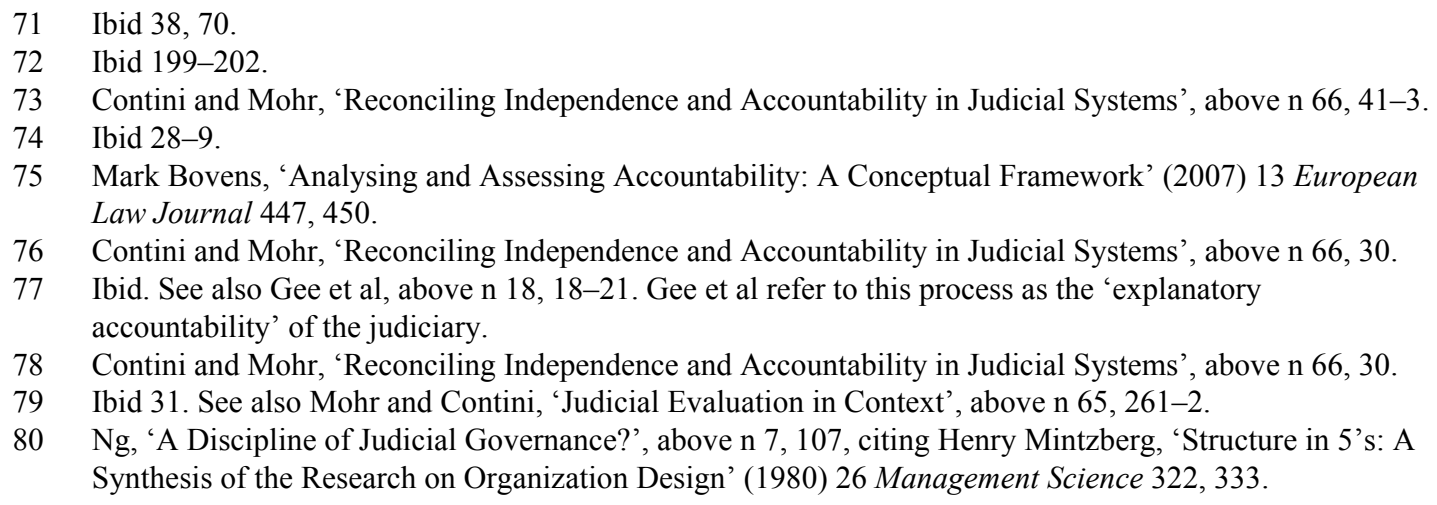


Mintzberg's typology, a professional bureaucracy is an organisational system that is centred around professional experts who perform highly complex and individualised work that cannot be easily standardised, measured or simplified. ${ }^{81}$ What is, in effect, being said, according to $\mathrm{Ng}$, is that 'judges can be difficult to manage', because they regard themselves as independent actors even when they are performing routine administrative tasks, and this creates substantial difficulties when it comes to evaluating, monitoring and improving court performance. ${ }^{82}$

$\mathrm{Ng}$ also points out that the problem of judicial administrative accountability became especially pronounced when the courts started to experience a steady rise in caseloads and judges realised that they were unable to accommodate the additional workload within their individual work routines. ${ }^{83}$ What was remarkable, according to $\mathrm{Ng}$, was that judges showed little inclination to coordinate their work activities with other judges and court staff, preferring instead to work alone, within the 'smallest unit within the organisation' ${ }^{84}$

Traditionally, judges also argued that they were not responsible for the growing social uncertainty that was caused by the accumulating delays, because they were not in charge of court administration. ${ }^{85}$ While there was truth in those arguments, for $\mathrm{Ng}$ this was an indication that judges and courts, as public institutions, failed to address the problem of organisational delay in accordance with their basic constitutional and human rights mandate. ${ }^{86}$ She concludes that the traditional mechanisms of ('hard') judicial accountability - such as the open nature of court proceedings, publication of reasoned judgments, availability of appellate review and scrutiny by the media - have all proved inadequate to respond to the public's demands of the courts. ${ }^{87}$

The impact of the traditional judicial administrative style on court performance was also considered in an international study commissioned by the European Commission for the Efficiency of Justice ('CEPEJ') in 2003. ${ }^{88}$ Professor Wim Voermans and Dr Pim Albers argue that courts are traditionally characterised by poorly defined, collegiate ('horizontal') administrative

81 Mintzberg, above n 80, 334, cited in Ng, 'A Discipline of Judicial Governance?', above n 7, 107.

$82 \mathrm{Ng}$, 'A Discipline of Judicial Governance?', above n 7, 108.

83 Gar Yein Ng, Quality of Judicial Organisation and Checks and Balances (PhD Thesis, Utrecht University, 2007) 24 .

84 Ibid 30.

85 Ibid 24, 30. See also, Courts Strategic Directions Project, above n 7, 75; Smith, above n 23; Peter A Sallmann and Richard T Wright, 'Extract on Courts' Governance From Going to Court, A Discussion Paper on Civil Justice in Victoria' (Paper presented at the $18^{\text {th }}$ Australian Institute for Judicial Administration Annual Conference, Darwin, 14-16 July 2000) 9.

$86 \mathrm{Ng}$, Quality of Judicial Organisation, above n 83, 13-15, 24, 30. Ng refers to the issue of organisational delay in the context of the Convention for the Protection of Human Rights and Fundamental Freedoms ('ECHR'), opened for signature 4 November 1950, 213 UNTS 221 (entered into force 3 September 1953) art 6(1), which provides that 'everyone is entitled to a fair and public hearing within a reasonable time by an independent and impartial tribunal established by law' (emphasis added); see also Charter of Human Rights and Responsibilities Act 2006 (Vic) s 25(2)(c), which provides that a person charged with a criminal offence is 'to be tried without unreasonable delay'.

$87 \mathrm{Ng}$, 'A Discipline of Judicial Governance?', above n 7, 24. See also Langbroek, 'Quality Management and Autonomy', above n 55, 10.

88 Voermans and Albers, 'Councils for the Judiciary', above n 48. 
structures that are primarily aimed at reaching a consensus among judges on all aspects of court administration. ${ }^{89}$ An illustrative example is the principal governing organs of the Victorian courts, which originated in the $19^{\text {th }}$ century and today consist of up to 100 judicial officers on the Council of Magistrates. Such large membership runs contrary to modern court administration and public administration theory according to which any governing organ with more than 15 members "inevitably" gives rise to "[s]erious problems of administration and of internal operation""..$^{90}$

Voermans and Albers also point out that the far-reaching organisational and interpersonal divide between judges and court staff contributes to organisational delay, by limiting the possibilities for workflow integration and the creation of deeper patterns of work delegation. ${ }^{91}$ As a result, court performance in this environment depends primarily on the personal commitment and individual professionalism of judges in the distribution and execution of their work, which is 'lacking on different fronts to provide an appropriate answer to the challenges [of] the increased case load'. ${ }^{92}$ The authors conclude, by reference to a series of empirical studies they had conducted in the Dutch courts in the 1990s, that more internally integrated and hierarchical ('vertical') judicial administrative structures are essential in order to improve court performance and transform the courts from the traditional 'organizations of professionals' to modern 'professional organizations'. ${ }^{93}$

\section{From 'Organisations of Professionals' to 'Professional Organisations'}

Historically, the introduction of formal administrative hierarchies within courts has been primarily associated with the so-called 'American models' of court administration, ${ }^{94}$ although the practice has been successfully adopted by the Australian federal courts and some European jurisdictions. ${ }^{95}$ One of the most remarkable features of the American model was the desire to formalise the administrative structures and relationships within the judiciary in the form of

89 Ibid 100.

90 Thomas W Church Jr, 'Administration of an Appellate Leviathan: Court Management in the Ninth Circuit Court of Appeals' in Arthur D Hellman (ed), Restructuring Justice: The Innovations of the Ninth Circuit and the Future of the Federal Courts (Cornell University Press, 1990) 226, 229, quoting Commission on the Revision of the Federal Court Appellate System, $92^{\text {nd }}$ Cong, The Geographical Boundaries of the Several Judicial Circuits: Recommendations for Change (Comm Print, 1973) 1. See also John Uhrig, 'Review of the Corporate Governance of Statutory Authorities and Office Holders' (Report, Commonwealth of Australia, June 2003) 96. The report points out that a board of between six and nine members represents a reasonable size in public entities.

91 Voermans and Albers, 'Geintegreerde Rechtbanken', above n 54, 72.

92 Voermans and Albers, 'Councils for the Judiciary', above n 48, 100-1.

93 Ibid 101, 108. See also Voermans and Albers, 'Geintegreerde Rechtbanken', above n 54, 70-2, 90-1.

94 Millar and Baar, above n 51, 54-5, 63.

95 In the US, the process of modern corporate transformation of the judiciary can be traced back to Roscoe Pound's address to the annual convention of the American Bar Association in 1906. It is worth recalling that two of the four 'causes of popular dissatisfaction with the administration of justice' that were identified by Pound were essentially problems of court administration; namely, 'judicial organization and procedure' and the 'environment of ... judicial administration'. See Roscoe Pound, 'The Causes of Popular Dissatisfaction with the Administration of Justice' (1906) 40 American Law Review 729, 730-1. 
highly transparent rules and regulations. ${ }^{96}$ For example, according to Wheeler, the Federal Circuit Councils in the US had been given formal statutory powers to ensure the 'effective and expeditious' disposition of cases and to issue administrative 'orders' that all individual judges had to comply with. ${ }^{97}$ Similarly, in the Australian federal courts, the legislation vested in the chief justices the administrative powers to ensure the 'effective, orderly and expeditious' discharge of the business of their courts, together with the corresponding powers to assign cases to particular judges and to temporarily restrict judges to non-sitting duties. ${ }^{98}$ According to Church and Sallmann, the key advantage of this approach to court management is that administrative accountability and authority are formally assigned to specific individuals, which means that responses to problems can be 'swift and consistent'. ${ }^{99}$

The most significant recent study that scrutinises the emergence of formal administrative hierarchies within the judiciary was completed in the UK in 2015. Gee et al examined the establishment of a formal judicial bureaucracy headed by the Lord Chief Justice and concluded that the corporatisation of the English and Welsh judiciaries was beneficial not only because it improved the judiciary's administrative capacity, but also because it had the effect of reinforcing judicial independence. ${ }^{100}$ According to the authors, the Constitutional Reform Act 2005 (UK) necessitated the creation of formal administrative relationships both within the judiciary and between the judiciary and the other branches of government. ${ }^{101}$ This process was primarily influenced by the exponential growth of the professional judiciary and partly also by a broader political drive to remodel the court system as a public service. ${ }^{102}$ In addition, there was a growing realisation among senior members of the judiciary that the 'mantra of judicial independence' had at times served to mask poor performance. ${ }^{103}$ Having interviewed more than 150 senior judges, parliamentarians, bureaucrats and ministers over a three year period, Gee et al concluded that the institutional reform had been largely successful and that the senior judiciary in England and Wales managed to '[pull] off a difficult trick' of preserving the essence of judicial independence, while also bringing about a genuine cultural shift towards greater institutional

96 See generally Russell R Wheeler, Origins of the Elements of Federal Court Governance (Federal Judicial Center, 1992). Examples of this practice can be found at all levels of the judicial organisation and across different State and Federal Circuits. See National Center for State Courts, 'Key Elements of an Effective Rule of Court on the Role of the Presiding Judge in the Trial Courts' (Report, National Center for State Courts, June 2006). See also the detailed rules of the Judicial Council of California: Judicial Council of California, California Rules of Court Title 10: Judicial Administration Rules (at 1 July 2016) $<$ http://www.courts.ca.gov/cms/rules/index.cfm?title=ten $>$.

97 Wheeler, above n 96, 18-19; Church and Sallmann, above n 16, 73.

98 Federal Court of Australia Act 1976 (Cth) s 15.

99 Church and Sallmann, above n 16, 68; See also Lou Hill, Constitutional and Managerial Principles of Judicial Court Governance: Implementation in the State of Victoria (LLM Thesis, University of Melbourne, 1995).

100 See generally Gee et al, above n 18, chs 6, 10.

101 Ibid 252-3.

102 Ibid 126.

103 Ibid 129-30. 
corporatism. ${ }^{104}$ Ultimately, the study found that the 'shift away from a culture of individualism towards one of corporatism' ${ }^{105}$ had significantly improved the judiciary's accountability and enhanced its institutional capacity to protect judicial independence. ${ }^{106}$

\section{Towards a 'New Elaboration' of Judicial Administrative Accountability}

The foregoing analysis provides the basis for a 'new elaboration' of judicial accountability in court administration. The analysis shows that the introduction of formal administrative hierarchies in courts can be justified in order to improve court performance, enhance the social legitimacy of the courts and reinforce judicial independence.

The remaining challenge for judges and policymakers is to devise a model policy framework for a judicial council and courts that would be capable of achieving these aims in practice. This issue will be considered next in the context of Millar and Baar's second policy challenge of judge-controlled systems of court administration.

\section{POLICY CHALLENGE TWO: ESTABLISHING A JUDICIAL COUNCIL THAT IS ACCOUNTABLE, RESPONSIVE AND EFFECTIVE}

The second policy challenge identified by Millar and Baar is to develop a policy framework for a judicial council and the courts that is not only independent and accountable, but also effective and capable of supporting the future development of the court system. ${ }^{107}$ In practical terms, the challenge is to identify the appropriate aims, competencies, composition, resources and other essential terms of reference for the judicial council, as well as to define its relationship with the courts and other branches of government. ${ }^{108}$ Each of the essential terms of reference will now be elaborated upon in more detail.

\section{A What Should be the Aims and Competencies of the Judicial Council?}

Recent history of justice sector reform shows that there is an emerging global trend of entrusting certain framework aspects of court governance to independent judicial councils, especially in countries that had previously relied on the executive government to manage the courts. Examples of this practice can be found across Europe, ${ }^{109}$ South America, ${ }^{110}$ North America, ${ }^{111}$ and Asia, ${ }^{112}$ as well

\footnotetext{
104 Ibid 155.

105 Ibid 126.

106 Ibid 101, 112. See also, generally, Malleson, The New Judiciary, above n 69.

107 Millar and Baar, above n 51, 70-1.

108 Ibid. They pointed out that many judicial councils in the US had been 'unable to establish any sort of accountability or develop adequate planning and policy development functions', because of unclear terms of reference or the absence of permanent administrative staff.

109 Ibid. The examples given by Voermans include Italy, France, Sweden, Ireland, Denmark, Norway, the Netherlands: Voermans, 'Councils for the Judiciary in Europe 2003', below n 114; Voermans and Albers,
} 
as Australia. ${ }^{113}$ According to Voermans, practically all judicial councils have been designed to operate as an institutional 'buffer' between the executive government and the courts, with the primary aim being that of safeguarding judicial independence. ${ }^{114}$ At the same time, the councils can also perform a wide range of operational and supervisory functions in the court system, such as supporting the administrative management of the courts and providing general oversight of their budget and other resources. ${ }^{115}$

Autheman and Elena conducted a comparative review of the judicial councils in more than 20 countries and found that the need to protect judicial independence was especially pronounced in Italy, France and several Latin American countries that had a long history of executive interference in the court system. ${ }^{116}$ As a result, the aims and competencies of the judicial councils in those countries have tended to focus primarily on matters impacting judicial tenure, such as the appointment, assignment and promotion of judges, and the conduct of disciplinary proceedings against judges. ${ }^{117}$ The same reasons were ostensibly behind the establishment of the judicial councils in the former communist states in Eastern Europe, which were largely modelled upon the Italian Consiglio Superiore della Magistratura. ${ }^{118}$ According to Bobek and Kosař, the defining characteristic of this model is a very robust, often constitutional, separation of the judicial council from the elected branches of government and other justice system stakeholders. ${ }^{119}$ Although some of these councils are also involved in court administration, the primary mission of each institution is to serve as a

'Councils for the Judiciary', above n 48. For Central and Eastern European judicial councils, see also Bobek and Kosař, above n 50, 1257.

110 Linn Hammergren, 'Do Judicial Councils Further Judicial Reform? Lessons from Latin America' (Rule of Law Working Paper No 28, Democracy and Rule of Law Project, Carnegie Endowment for International Peace, June 2002). The examples given by Hammergren include El Salvador, Peru, Mexico and Colombia.

111 Millar and Baar, above n 51, 70-1. The authors give the examples of Ontario, Canada, the Judicial Conference of the US and several states in the US.

112 For example, the Judicial Commission of Indonesia was established in 2001.

113 See King, 'A Judiciary-based State Courts Administration', above n 10. Chief Justice King gives the example of the South Australian Judicial Council. See also Vince Morabito, 'The Judicial Officers Act 1986 (NSW): A Dangerous Precedent or a Model to Be Followed?' (1993) 16 University of New South Wales Law Journal 481. The example given by Morabito is the Judicial Commission of New South Wales. The most recent example is Court Services Victoria: see Court Services Victoria Act 2014 (Vic).

114 Wim Voermans, 'Councils for the Judiciary in Europe: Trends and Models' in Francisco Fernández Segado (ed), The Spanish Constitution in the European Constitutional Context (Dykinson, 2003) 2133, 2140.

115 Violaine Autheman and Sandra Elena, 'Global Best Practices: Judicial Councils - Lessons Learned from Europe and Latin America' (Rule of Law White Paper, International Foundation for Electoral Systems, April 2004) 3.

116 Ibid 2. See also Garoupa and Ginsburg, below n 126, 3-6; Bobek and Kosař, above n 50; Hammergren, above n 110; Voermans and Albers, 'Councils for the Judiciary', above n 48, 59, 65, 76-7.

117 Autheman and Elena, above n 115, 2, 28-9. The authors give the examples of Italy, France, Bolivia, Argentina, Mexico, Peru and other countries.

118 Bobek and Kosař, above n 50, 1268.

119 Ibid. 
supreme judicial authority with controlling competencies over all aspects of the judicial career. ${ }^{120}$

In contrast, the judicial councils that operate in countries with a more established tradition of judicial independence usually place a far greater emphasis on the practical aspects of court administration, such as budget management, ${ }^{121}$ court management, ${ }^{122}$ policy advice, ${ }^{123}$ data collection, ${ }^{124}$ and judicial education and training. ${ }^{125}$ Bobek and Kosař broadly classify these types of councils as belonging to the 'Court Service model', while Voermans refers to them as the 'Northern European Model'. ${ }^{126}$ Indeed, the preference for a service-oriented council has been particularly pronounced in the Northern European countries, following the establishment of the judicial councils in Sweden (1975), Ireland (1998), Denmark (1999), Norway (2002) and the Netherlands (2002). ${ }^{127}$ In each of these countries, the primary concern was not only to protect judicial independence, but also to improve court performance, achieve greater customer focus in the court system and bring about an institutional renewal of the judiciary as a whole. ${ }^{128}$ As Byrne and McCutcheon point out in their analysis of the Irish Courts Service, there was a:

fundamental shift in the "philosophy" of the courts system, requiring it to take account of the concepts of quality, service and competitiveness more associated heretofore with the private sector ... [T] "court system" to "court service". ${ }^{129}$

Another important requirement for a service-oriented judicial council is to have the necessary organisational competencies to support the future development of the court system, in order to compensate for the withdrawal of the executive government from that area of responsibility. ${ }^{130}$ According to Voermans and Albers, this issue essentially refers to the court system's capacity to innovate and effect systematic improvements in the quality of the

120 Ibid.

121 Examples include the judicial councils in Ireland, Norway, Sweden and the US.

122 Examples include the judicial councils in the US, Ireland and South Australia.

123 Examples include the judicial councils in the US, the Netherlands, Denmark, Sweden and South Australia.

124 Examples include the judicial councils in Ireland, South Australia and the US.

125 Autheman and Elena, above n 115, 2, 28-9. The examples include the councils in Sweden and the Netherlands.

126 Bobek and Kosař, above n 50, 1264; Wim Voermans, 'Councils for the Judiciary in Europe' (2000) 8 Tilburg Foreign Law Review 121; see also Nuno Garoupa and Tom Ginsburg, 'The Economics of Judicial Councils' (Latin American and Caribbean Law and Economics Association ('ALACDE') Annual Paper, University of California, Berkeley, 25 February 2007). Notably, Bobek and Kosař and Garoupa and Ginsburg reject Voermans' classification as being unhelpful, because some of the judicial councils come from the US and other non-European countries.

127 See generally Voermans and Albers, 'Councils for the Judiciary', above n 48.

128 W J Deetman et al, 'Judiciary is Quality' (Committee for the Evaluation of the Modernisation of the Dutch Judiciary, December 2006) 7-8.

129 Raymond Byrne and J Paul McCutcheon, The Irish Legal System (LexisNexis Butterworths, 4th ed, 2001) 155-6. Notably, many of these issues had also been highlighted in Australia in the Parker Report, which identified the need for the courts to become 'learning organisations' and to 'improve the level of two-way communication they enjoy with their public': see Parker, above n 1, v.

130 Millar and Baar, above n 51, 70-1. 
administration of justice in a far more demanding social, technological, political and legal environment: ${ }^{131}$

These new quality requirements call for efficient streamlining of the working processes within the courts, judicial precision during procedures, permanent training of judges and auxiliary staff, uniformity in applying substantive and procedural law, correct treatment, avoidance of long waiting periods, guarantees concerning the speed of settlement, etc. ${ }^{132}$

Professor ten Berge explains how a service-oriented judicial council can contribute to the expansion of the judiciary's administrative capacity in each of these areas by promoting the efficiency, client-orientation and quality of courts as important public institutions. ${ }^{133}$ First, the council can offer technical assistance to the courts in devising new approaches to case management, procedural and organisational accessibility. Second, it can provide various forms of professional support, such as advanced legal research, in order to improve the quality of legal outcomes in individual cases or categories of cases. Third, the council can offer management support by assisting the courts to devise best practice organisational policies and competencies for judges and court staff. Fourth, it can promote greater use of Information Communication Technology ('ICT') platforms to improve business and legal process analytics and develop more systematic approaches to training, education and professional development for judges and staff. Fifth, from a customer service point of view, the courts would benefit from more uniform policies on customer service and other organisational solutions that place a greater focus on the needs of their customers. Finally, at a broader systemic and political level, the council can establish the necessary legislative and policy proposals on issues impacting the courts and develop appropriate institutional relationships with the government and other justice system stakeholders. ${ }^{134}$

\section{B Who Should be Represented on the Council?}

In their analysis of the Eastern European judicial councils, Bobek and Kosař identified the 'problem of representation' as a major objection to any council that relies exclusively on a narrow group of chief judges and court presidents. ${ }^{135}$ They describe the negative experiences of the Slovak Judicial Council and warn that the very concept of judicial self-governance can quickly turn into 'unbounded administration by senior judicial officials' ${ }^{136}$ Their views are consistent with the findings of Linn Hammergren's comparative study of Latin American judicial councils, which identified a series of shortcomings of this model, such as the spread of internal political factions, a lack of accountability to the community

131 Voermans and Albers, 'Councils for the Judiciary', above n 48, 100-1.

132 Ibid 102.

133 J B J M ten Berge, 'Contouren van Een Kwaliteitsbeleid voor de Rechtspraak' in P M Langbroek, K Lahuis and J B J M ten Berge (eds), Kwaliteit van rechtspraak op de weegschaal (Deventer, 1998) 21 , 31-5, cited in Ng, Quality of Judicial Organisation, above n 83, 30-2.

134 Ibid 32-3.

135 Bobek and Kosař, above n 50, 1270.

136 Ibid 1271. 
and concerns about individual judicial independence. ${ }^{137} \mathrm{~A}$ similar point is also made by Millar and Baar, who chronicled the experiences of a range of judicial councils across the US and Canada. They express strong criticism of the socalled Ontario model, which involved a judicial council made up exclusively of the chief judges of the participating courts, ${ }^{138}$ a model which is commonly found in many US jurisdictions, but also in South Australia and, most recently, Victoria.They particularly highlighted the fact that although the key motivation for establishing the judicial council was to separate court administration from executive control, each chief judge on the council was selected by the executive government, rather than members of the judiciary..$^{139}$

The problem of permanent or exclusive judicial representation on the council also has important management and community aspects that should not be disregarded. First, as Sallmann and Wright have pointed out, chief justices are often appointed for their legal expertise and therefore may not be 'best suited to exercise policy making and management functions' on the judicial council. ${ }^{140}$ Secondly, permanent composition of the council could lead to personality clashes, which are common in environments where people need to work together for long periods of time. ${ }^{141}$ Thirdly, this type of institutional arrangement could potentially foment ongoing factional disputes and lead to a competition for administrative resources. ${ }^{142}$ Finally, Glanfield emphasises the broader community aspect of court administration to argue that community needs and expectations must be built into the organisational framework as a guiding design principle of court governance. ${ }^{143} \mathrm{He}$ points out that increasing community expectations lie behind recent advances in governance thinking about the issues such as ethics, efficiency, timeliness and accountability. ${ }^{144}$ Arguably, then, a judicial council that is composed solely of the chief judges potentially lacks the necessary community perspective and may also diminish the capacity and responsibility of other judges to be involved in the management affairs of the court system. ${ }^{145}$

The recent experiences of Northern European countries should also be noted in this context. The judicial councils in Denmark, Norway, Ireland, Sweden and the Netherlands have enshrined broader stakeholder participation on the governing (supervisory) boards that in many cases rely exclusively on fixed term appointments based on merit. For example, in Norway, the board of the National Courts Administration has nine members, including four judges, one court

137 Hammergren, above n 110, 3.

138 Millar and Baar, above n 51, 69-73. Notably, however, in Victoria, the legislation leaves open the possibility for the chief justices to appoint up to two non-judicial members on the Courts Council. See Court Services Victoria Act 2014 (Vic) s 14(1). For a detailed analysis of the Victorian reform, see Bunjevac, 'Court Services Victoria and the New Politics of Judicial Independence', above n 32.

139 Ibid.

140 Sallmann and Wright, above n 85, 9.

141 Ibid.

142 Des Semple, 'Future Governance Options for Federal Family Law Courts in Australia: Striking the Right Balance' (Report, Attorney-General's Department, 2008) 25, 48-51.

143 Glanfield, above n 46, 5.

144 Ibid.

145 Alford, Gustavson and Williams, above n 24, 91. 
executive and two lawyers appointed by government, together with two representatives of the public, who are appointed by Parliament. ${ }^{146}$ In Ireland there are 17 members on the board of the Irish Courts Service, including nine judicial members and eight representatives from the government, trade unions, members of parliament and lawyers' associations. ${ }^{147}$ The rationale behind the inclusion of non-judicial members and fixed term appointees on the board lies in the belief that this practice enhances the social accountability of the organisation and leads to greater professionalisation and depoliticisation of court administration. ${ }^{148}$

\section{What Function(s) Should the Judicial Council Perform in Court Administration and How Should the Courts be Organised Internally?}

The establishment of a judicial council also raises important questions about its role in court administration and its relationship with the courts. For example, it is important to define how the new entity should interact with the individual courts, both in terms of their day-to-day operations and also in terms of their policy development and strategic oversight. Alford, Gustavson and Williams explain that this is a complex question from a management perspective, because the optimal organisational design ultimately depends on factors such as the size of the jurisdiction and the need to better optimise non-judicial resources, such as administration, infrastructure, finances, ICT and other shared services. ${ }^{149}$ They suggest that centralised control of staffing, operations and infrastructure would probably work well in smaller jurisdictions, such as South Australia, but not in larger jurisdictions, such as Victoria, because larger organisational units start to exhibit 'diseconomies of scale', accompanied by lower staff satisfaction and commitment to the organisation. ${ }^{150}$ These issues were also noted by Church and Sallmann in their analysis of the Judicial Conference of the United States and its central administrative arm, the Administrative Office of the United States Courts. ${ }^{151}$ They noted that the early American court reformers recognised the importance of preserving individual courts' operational autonomy, by leaving certain aspects of court administration, such as case processing, staff selection and management, in most cases to the courts themselves. ${ }^{152}$ This practice allowed individual jurisdictions and Federal Circuits to develop innovative administrative rules and practices that were remarkably transparent and functional at the same time. ${ }^{153}$

146 Arvid Rosseland (ed), 'Presentation of the National Courts Administration and the Norwegian Court Reforms of 2002' (2007) 51 Scandinavian Studies in Law 608, 612.

147 See Courts Service Act 1998 (Ireland) s 11.

148 Bunjevac, 'Court Governance in Context: Beyond Independence', above n 1, 43.

149 Alford, Gustavson and Williams, above n 24, 53-67.

150 Ibid 62-3, 66-7. The authors refer to the writings of the influential management theorists Peters and Waterman, who identified the so-called ' 1000 -staff rule of thumb', representing the optimum division size in successful companies. See Thomas J Peters and Robert H Waterman Jr, In Search of Excellence: Lessons From America's Best-Run Companies (Harper and Row, 1982) 272-3.

151 Church and Sallmann, above n 16, 72-3.

152 Ibid 74.

153 For example, Omnibus Judgeship Act of 1978, Pub L No 95-486, § 6, 92 Stat 1629 allowed courts of appeal with more than 15 judges to experiment with internal administrative units. The administrative 
The relationship between the judicial council and courts also has an important judicial management dimension that should not be overlooked in allocating the operational responsibilities between the council and the courts. According to Baar et al, great care must be taken to ensure that the new institutional framework does not repeat the ills of the executive system of court administration. ${ }^{154}$ They give the example of the Courts Administration Service ('CAS') in the Canadian federal jurisdictions, which merely replicated the ineffective management patterns that had been established earlier by the executive government. Notably, this was the case despite the fact that the CAS administration was independent of the executive government and was also subject to the directions by the chief justices of the participating courts. ${ }^{155}$ The underlying problem identified by Baar et al was that judges had simply continued to rely on the CAS bureaucracy to centrally plan and manage all aspects of the court operations, which in their view rendered this model in practice a variant of the executive model. ${ }^{156}$ As a result, according to Baar et al, the chief justices' formal powers to intervene in court administration were of limited practical utility in the circumstances, because the judiciary's lack of systematic involvement in court operations had made it difficult to determine whether any direction to CAS was needed in the first place. ${ }^{157}$

\section{Integrated Management in the Courts}

The importance of greater judicial involvement in court management was also highlighted in the CEPEJ report, which discussed the example of the Swedish National Courts Administration ('SNCA') and its relationship with the courts. According to Voermans and Albers, the most significant feature of SNCA is that it does not have any operational powers in court administration. ${ }^{158}$ Instead, its main task is to support the court operations from a distance, by managing certain shared services and facilities, such as human resources, ICT, auditing and accounting systems, security and so on. ${ }^{159}$ In practice, SNCA also offers various forms of professional and developmental support to the courts, such as legal assistance, policy advice and management training for judges and court staff. ${ }^{160}$

For their part, the Swedish courts operate largely autonomously, with each court having full responsibility for their own budgetary, financial, administrative

innovations of the Ninth Circuit Court of Appeal, in particular, have been well-documented and studied around the world: see, eg, Church Jr, above n 90; see also McGarvie, 'The Foundations of Judicial Independence in a Modern Democracy', above n 17, 30.

154 Baar et al, above n 22, 102-3.

155 Ibid.

156 Ibid.

157 Ibid 103.

158 Voermans and Albers, 'Councils for the Judiciary', above n 48, 22-3.

159 Ibid.

160 Ibid. See also Domstolsverket (Swedish National Courts Administration), 'Operational Plan 2010-2012' (Report, 2009); see also John Bell, 'Sweden's Contribution to Governance of the Judiciary' (2007) 50 Scandinavian Studies in Law 83, 98; Voermans, 'Council for the Judiciary in Europe 2003', above n 114, 2139-40. 
and personnel management affairs. ${ }^{161}$ A key advantage of this system, according to Voermans and Albers, is that it effectively integrates all of the judicial and administrative functions under a single executive court authority, thereby avoiding potential duplication of operational competencies between the courts and the council. ${ }^{162}$ Furthermore, the fact that SNCA does not interfere in the courts' operational management effectively forces the courts to become more self-sufficient as organisations, thus promoting more active involvement of judges in court administration. ${ }^{163}$ According to the authors, the Swedish judiciary is strongly attached to the system of integrated management, because it 'promotes self-responsibility for the primary process' and 'increase[s] efficiency'. ${ }^{164}$

The Australian federal courts' experiences with the system of integrated management should also be mentioned in this context due to a number of similarities and differences with their Swedish counterparts. The similarities lie in the effective integration of the administrative, financial, operational and judicial responsibilities under the courts' own umbrella, which has allowed the federal courts to develop more business-like strategic planning and operational capabilities. ${ }^{165}$ Secondly, according to the former Chief Justice of the Federal Court, Michael Black, integrated management has brought judges into an 'appropriate working relationship with professional administrators'. ${ }^{166}$ As a result, the federal courts have made some remarkable achievements in areas such as judicial innovation, ${ }^{167}$ benchmarking and productivity for the judiciary, ${ }^{168}$ case management reform, ${ }^{169}$ and even the promotion of outreach projects for overseas judiciaries. ${ }^{170}$

Nevertheless, there are also a number of potential drawbacks associated with the federal courts' self-management system, which set this model apart from its Swedish counterpart. The most obvious difference is that there is no judicial council interposed between the courts and the executive government, which makes the Australian federal courts arguably much more vulnerable to executive

161 Voermans and Albers, 'Councils for the Judiciary', above n 48, 108.

162 Ibid 24, 108

163 Ibid 108.

164 Ibid 108-9.

165 Warwick Soden, 'The Application of International Court Excellence Framework within the Federal Court of Australia with a Special Look at Strategic Planning to Achieve Excellence' (Paper presented at the Asia-Pacific Courts Conference, Singapore, 4-6 October 2010) 4-5.

166 Chief Justice Michael E J Black, 'The Federal Court of Australia: The First 30 Years - A Survey on the Occasion of Two Anniversaries' (2007) 31 Melbourne University Law Review 1017, 1047. See also ibid.

167 Black, above n 166, 1048-50.

168 Justice Stephen O'Ryan and Tony Lansdell, 'Benchmarking and Productivity for the Judiciary' (2000) 10 Journal of Judicial Administration 25.

169 Caroline Sage and Ted Wright, 'Case Management Reform: A Study of the Federal Court's Individual Docket System' (Report, Law and Justice Foundation of New South Wales, June 2002); Natacha Vsindilok, A Comparison of the Case Flow Management and Case Tracking Systems of the Central Administrative Court of Thailand with Those of the Federal Court of Australia, with Reference to Practice in the USA (LLM Thesis, University of Wollongong, 2004).

170 See Soden, above n 165, 4. See also A M North, 'My Court Car is a Helicopter!' (Speech delivered at the Canadian Judicial Council Conference - 'Inside the Administration of Justice: Toward a New Model of Court Administration', Victoria, British Columbia, 31 January 2007). 
interference. Professor Anne Wallace illustrates this point by reference to the recent centralisation of the federal courts' corporate services under the umbrella of the Federal Court of Australia, which was prompted by ongoing financial and operational difficulties experienced by the Federal Circuit Court and the Family Court of Australia. ${ }^{171}$ According to Wallace, the initiative was principally 'driven by the executive, rather than the courts, and motivated primarily by reducing costs', rather than a genuine need to improve services for court users. ${ }^{172}$

This example also demonstrates that there can be significant financial and reputational risks associated with each court having the responsibility for operational management while also having to report directly to the executive government. One of the negative consequences of this situation is that the occasional budget overruns may be interpreted as signs of financial incompetence, thus potentially significantly eroding the public confidence in the judiciary. ${ }^{173}$

The absence of a judicial council could also have negative ramifications from a wider systemic perspective, because it potentially discourages individual courts from taking a broader view of problems affecting the justice system. ${ }^{174}$ Skehill argues that this is not a major concern in the specific context of the federal courts, because each federal court was designed to operate as a standalone jurisdiction, rather than as part of a unified 'system' of the administration of justice. ${ }^{175}$ In contrast, however, the need for greater systemic oversight would arguably be felt much more strongly in a state jurisdiction such as Victoria, where the separate court tiers do form part of an integrated system of the administration of justice. Accordingly, in that situation, the existence of a judicial council could prove to be instrumental in addressing the identified deficiencies of the federal courts model, by offering an additional layer of protection, expertise and oversight to the courts.

171 Anne Wallace, 'Merging Federal Courts' Administration Won't Improve Services for Those Who Need It', The Conversation (online), 4 November $2015<\mathrm{http}$ //theconversation.com/merging-federal-courtsadministration-wont-improve-services-for-those-who-need-it-49944>. See also the Courts Administration Legislation Amendment Act 2016 (Cth). The Act amended s 38A(1) of the Family Law Act 1975 (Cth) to specify that the corporate services of the Court include communications, finance, human resources, information technology, libraries, procurement, contract management, property, risk oversight and management, and statistics. See also Stephen Skehill, 'Strategic Review of Small and Medium Agencies in the Attorney-General's Portfolio' (Report, Australian Government, January 2012) 27. The review predicted increasing annual deficits in the federal jurisdictions reaching $\$ 19.5$ million by $2014-15$.

172 Wallace, above n 171.

173 Michael Pelly, 'Federal Magistrates Court Audit Uncovers \$5m Black Hole', The Australian (online), 6 March $2009<$ http://www.theaustralian.com.au/business/legal-affairs/courts-5m-budget-blowout/storye6frg97x-1111119045969>. The article criticises the court for using the MYOB accounting software, which is designed for a small business, rather than a court with a budget of more than $\$ 55$ million. See also Nicola Berkovic, 'Diana Bryant Calls for Federal Overseer', The Australian (online), 26 September $2014<$ http://www.theaustralian.com.au/business/legal-affairs/diana-bryant-backs-calls-for-federaloverseer/story-e6frg97x-1227070718146>. According to the article, a report by KPMG forecast Family Court and Federal Circuit Court budgetary shortfalls of up to $\$ 75$ million by $2017-18$, which prompted the executive government to look at reforming the system of court administration in the federal courts.

174 Church and Sallmann, above n 16, 68-71.

175 Skehill, 'Comment on Court Governance', above n 34, 29. 
The final point of difference between the Swedish system of integrated management and the Australian federal courts concerns their internal administrative arrangements. Namely, the Swedish courts are governed by a small collegiate presidium elected by the councils of judges, which stands in sharp contrast to the chief justice governance model that operates in the federal courts. ${ }^{176}$ The latter has been the subject of criticism, because it concentrates too much administrative power in the chief justices, possibly at the expense of other judicial officers. ${ }^{177}$ According to Hill, the arrangement also runs contrary to modern business practices that encourage more collegiate decision-making at the policymaking level. ${ }^{178}$

\section{What Role Should the Minister Perform in the New Institutional Framework?}

The establishment of a judicial council represents a significant legal and political challenge for the court system as a whole, because it requires a wholesale redefinition of the duties and responsibilities of all three branches of government in the area of court administration. In theory, at least, the redistribution of power is intended to reduce the 'traditional tensions' between the judiciary and other branches of government, because of the 'corresponding increase in judicial self-responsibility' and independence. ${ }^{179}$ However, as Baar et al remind us, the judiciary's autonomy remains limited, not least because the courts will always be financially dependent on the elected branches of government. ${ }^{180}$ At the same time, the Attorney-General continues to exercise broad political responsibility for the operation of the courts, because under the Westminster system of government there must always be a Minister of the Crown who is responsible for the expenditure of public funds. ${ }^{181}$ In addition, apart from the responsibility for public finances, the government also has other legitimate interests in the proper operation of the court system that may potentially justify some form of ongoing ministerial involvement in court administration. Therefore, one of the key challenges for judges and policymakers is to define the new limits of ministerial responsibility for the operations of the courts, in the circumstances where the Attorney-General's ability to influence the court administration (and vice versa) is objectively diminished.

176 Voermans and Albers, 'Councils for the Judiciary', above n 48, 23.

177 Church and Sallmann, above n 16, 68. The authors argue that this arrangement can potentially 'retard' the development of administrative capacity in the courts. However, see Chief Justice Diana Bryant, 'The Autonomous Model - Not All Beer and Skittles' (Paper presented at the the Judicial Conference of Australia Colloquium, Hyatt Hotel, Canberra, 6-8 October 2006). The Chief Justice of the Family Court of Australia explains that in reality the administrative powers are exercised in a collegiate manner.

178 Hill, above n 99, 74-5, 82-3.

179 Bunjevac, 'Court Governance: The Challenge of Change', above n 8, 210.

180 Baar et al, above n 22, 104.

181 King, 'A Judiciary-based State Courts Administration', above n 10, 142. Chief Justice King points out that the key difference between the Westminster System and the American models is that in the US judges deal directly with Congress, whereas in the Westminster System there must always be a Minister who is responsible to Parliament for the expenditure of public money. 


\section{Minister's Reserve Powers in Court Administration}

As foreshadowed, there are many legitimate reasons justifying ongoing involvement of the Minister in court administration. The first concerns the ability of the government to effectively deliver a suite of justice sector services to the public that are deeply intertwined with the work of courts, such as public prosecutions, corrections, legal aid and so on. Secondly, as Chief Justice Leonard King pointed out, the government also has a legitimate interest in the judiciary's decisions about issues such as the locations, openings and closings of court houses. ${ }^{182}$ Thirdly, the electorate will always regard the administration of justice in the courts as an essential public service, which means that the government may be held to be politically responsible for the proper operations of the courts, regardless of who is formally in control of court administration. ${ }^{183}$ Arguably, then, when politically sensitive incidents involving the courts do arise, the Minister will be under enormous political pressure to respond 'in order to appease the government and the electorate'. ${ }^{184}$ This may be the case even if the judicial council is statutorily responsible for the operation of the courts, because, as Voermans and Albers explain in the context of the Irish Courts Service, 'the line of a Minister's political responsibility to Parliament has different dynamics than that of the much slower and less direct line of responsibility that the Courts Service has with Parliament'. ${ }^{185}$

For reasons identified above, there is an emerging trend in jurisdictions that have recently established a service-oriented judicial council of entrusting a range of residual court administration functions to the Minister. One important exception to this trend is South Australia, where the relationship between the Attorney-General and the Judicial Council appears to be tilted conclusively towards the judiciary. According to former Chief Justice King, the AttorneyGeneral is principally responsible for presenting the judiciary's budget to Parliament, and is also entitled to receive adequate information about the operations of the courts. ${ }^{186}$ Apart from that, however, he or she has "no control over the decisions of the Court Administration Authority and consequently no direct responsibility for them' ${ }^{187}$ This position is clearly reflected in the South Australian legislation, which explicitly provides that a member of the Council or the CEO must attend a Parliamentary Estimates Committee to answer questions about the courts' operations and expenditure of money. ${ }^{188}$ While at first this may be seen to be inconsistent with the idea of judicial independence, the Chief

182 Ibid 141-2.

183 Uhrig, above n 90, 42. The Uhrig Report gives the example of the Civil Aviation Safety Authority ('CASA'), which was previously managed by a board independent of the Minister. However, following a number of aviation safety incidents, the 'community expected the Minister to be accountable for the performance of the authority'. This prompted the government to take a greater role in the operation of CASA.

184 Bunjevac, 'Court Services Victoria and the New Politics of Judicial Independence', above n 32, 323.

185 Voermans and Albers, 'Councils for the Judiciary', above n 48, 33.

186 King, 'A Judiciary-based State Courts Administration', above n 10, 142.

187 Ibid 140-1. More recently, Victoria has also opted for a minimalist role for the Attorney-General: see Bunjevac, above n 32, 322-4. King, 'A Judiciary-based State Courts Administration', above n 10, 140-1.

Courts Administration Act 1993 (SA) s 29. 
Justice explains that he would be attending the Estimates hearings in his administrative capacity as the Chairman of the Judicial Council. ${ }^{189}$

In contrast to South Australia, however, in the Northern European jurisdictions the Minister's responsibility for certain threshold questions impacting the operations of the courts has not been removed in its entirety. For example, in Ireland, the legislation implicitly recognises that the government should have a say in the administrative affairs of the court system by requiring the Irish Courts Service to obtain the Minister's approval of its strategic plans. ${ }^{190}$ Secondly, the Courts Service is also required by law to 'have regard to any policy or objective of the Government' that may affect the operations of the courts. ${ }^{191}$ Next, in Sweden and the Netherlands, the government and the Minister, respectively, are also entitled to issue broad general directions to the judicial council with a view to ensuring proper operations of the courts, as long as the judicial council considers them to be compatible with the principle of judicial independence. ${ }^{192}$

In some countries, the justice minister also retains certain 'reserve' powers in court administration that may only be invoked in cases of clearly defined emergency. For example, in Denmark and the Netherlands, the Minister may be entitled to suspend decisions or even dismiss the board of the judicial council where the Auditor-General discovers significant financial irregularities in the management of the courts' budget, or the council makes decisions that are 'manifestly contrary to the law' ${ }^{193}$ Notably, however, this solution is only made possible because of the non-permanent composition of the councils, which clearly highlights the potential reputational risks that would be associated with permanent membership in like circumstances. ${ }^{194}$

Another example of the Minister's ongoing involvement in court administration is found in England and Wales, where control over court administration is currently shared between the judiciary and the executive government in accordance with a formal partnership agreement. ${ }^{195}$ The policy rationale behind the Lord Chancellor's continuing role in court administration is partly based on an implicit recognition that the 'courts are by their nature a

189 King, 'A Judiciary-based State Courts Administration', above n 10, 140.

190 Courts Service Act 1998 (Ireland) s 7. In addition, there are representatives of the executive government on the Board of the Courts Service.

191 Courts Service Act 1998 (Ireland) s 13.

192 Judiciary (Organisation) Act 1827 (Netherlands) art 93. See also Domstolsverket (Swedish National Courts Association), above n 160, 8.

193 Jesper, Wittrup and Poul Sørensen, 'Quality and Justice in Denmark' in Marco Fabri, Phillip M Langbroek and Hélène Pauliat (eds), The Administration of Justice in Europe: Towards the Development of Quality Standards (Research Institute on Judicial Systems, National Research Council, 2003) 119, 125. See also Judiciary (Organisation) Act 1827 (Netherlands) arts 106, 107. The legislation also provides the rights for appealing the Minister's decision to suspend or dismiss members of the council in the Supreme Court: at art 108.

194 Bunjevac, 'Court Services Victoria and the New Poitics of Judicial Independence', above n 32, 323.

195 But see Letter from Lord Chief Justice Igor Judge to the Lord Chancellor Chris Grayling, 9 May 2013 $<$ http://www.theguardian.com/law/interactive/2013/jun/25/courts-privatisation-igor-judge-chrisgrayling $>$. The Lord Chief Justice is proposing the establishment of a new courts and tribunals service that would be independent of executive control. 
shared responsibility between the judiciary and government'. ${ }^{196}$ Thus under the Courts Act 2003 (UK) and the partnership agreement, the Lord Chancellor continues to be politically responsible for the courts and also has an important say over the policies of Her Majesty's Courts and Tribunals Service. ${ }^{197}$ Remarkably, however, under the partnership agreement he is also entitled to make 'whatever decision ... he considers appropriate' in the event of disagreement with the Lord Chief Justice. ${ }^{198}$ Arguably, the Lord Chancellor's power of intervention in England and Wales is too unconstrained, especially when compared with Denmark or the Netherlands. The problem lies in the fact that the powers of intervention may be invoked arbitrarily and without any reference to specific emergencies or misconduct by the judicial council. ${ }^{199}$

\section{Influencing and Engaging Politics through Greater Corporatisation}

A separate issue affecting the relationship between the judicial council and the executive government concerns the ability of the judiciary to maintain sufficient institutional visibility in the political arena, in circumstances where the Attorney-General's political priorities and influence on the Cabinet have substantially changed. ${ }^{200}$ According to Kathy Laster, there is a 'real danger' that the courts might find themselves struggling for resources in this environment, because they may be left to their own devices when it comes to securing funds during the highly competitive and often politicised budget bidding processes. ${ }^{201}$ This issue was also highlighted by Gee et al in their landmark study of the politics of judicial independence in the UK, which identified the 'retreat of the politicians' as being a 'primary challenge' for the independent judiciary in that country. ${ }^{202}$ They pointed out that the nature of the political processes affecting the judiciary had changed substantially following the introduction of the Constitutional Reform Act 2005 (UK), because the relationships between the judiciary and the other branches of government had become much more dispersed, formal, open and accountable than before. ${ }^{203}$ At the same time, the institutional separation of the Lord Chancellor from the judiciary had also meant that the position no longer commanded the same degree of political power, prestige or influence as before. ${ }^{204}$ According to Gee et al, the judiciary's survival in that environment required greater institutional corporatisation, political astuteness and strategic engagement with a much wider range of political

196 Lord Chief Justice Philips, 'The Lord Chief Justice's Review of the Administration of Justice in the Courts' (Report, Judiciary of England and Wales, March 2008) 7, 16.

197 Courts Act 2003 (UK) c 39, s 1. See also Lord Chancellor, 'HM Courts \& Tribunals Service: Framework Document' (Report, HM Courts \& Tribunals Service, July 2014).

198 Ibid 19 [10.4].

199 Bunjevac, 'Court Governance: The Challenge of Change', above n 8, 216-17.

200 Gee et al, above n 18, 35, 253-4; Bunjevac, 'Court Services Victoria and the New Poitics of Judicial Independence', above n 32, 324.

201 Kathy Laster, 'Separation of Powers through Separation of Administration?' (2011) 36 Alternative Law Journal 135.

202 Gee et al, above n 18, 262.

203 See generally ibid ch 10.

204 Ibid 253-4. 
actors and institutions, including the Parliament. ${ }^{205}$ They concluded that the development of a more formal judicial bureaucracy with clearly defined organisational structures and powers had been the key to meeting the new challenges and enhancing the judiciary's institutional capacity to protect judicial independence. ${ }^{206}$

\section{E What Mechanisms Should be Introduced to Promote Transparent and Accountable Relationships with the Executive Government and Stakeholders?}

As Gee et al pointed out, the likely success or otherwise of any court system reform ultimately depends on the quality of the interaction between the courts, government and other justice system stakeholders. The importance of this issue cannot be overstated, because the Attorney-General's department had previously had complete day-to-day (vertical) insight into the court system's operations, human resources and finances - precisely those levers of power that have now been transferred to the judiciary. The question arises, then, what statutory or nonstatutory safeguards should be left in place in order to give the government, parliament and other interested parties an objective insight into the internal operations of the judicial organisation that is funded by the taxpayer?

It has been argued throughout the article that future institutional relationships between the judiciary and its stakeholders must be rooted in the concepts of organisational transparency and administrative accountability. ${ }^{207}$ According to Langbroek, the traditional, 'vertical', forms of administrative accountability between the courts and government must be transformed into more transparent, 'horizontal', accountability relationships between the courts and the government on the one hand, and the courts and the public on the other. ${ }^{208}$ That transformation can take place in many different ways, such as through the adoption of more systematic and robust approaches to internal business processes, the introduction of clearly defined administrative duties and responsibilities, and even the development of modern workload measurement systems for the courts that can be used for the purposes of strategic planning and budget formulation. Arguably, the adoption of these and similar measures by the courts would serve to promote greater institutional corporatisation of the courts and enhance the quality and accountability of court administration.

\section{$1 \quad$ Introduction of Quality Management Systems}

Langbroek envisages more widespread adoption of modern quality management systems by the courts as a means of furthering organisational selfimprovement, engendering public trust and compensating for reduced central

205 Ibid 253-4, 263.

206 Ibid 101, 112. See generally Malleson, The New Judiciary, above n 69.

207 Langbroek, 'Quality Management and Autonomy', above n 55, 6.

208 Ibid 6. See also Baar et al, above n 22, 104. According to Baar et al, 'it is through the provision of timely, accurate and comprehensive information to the Legislature and to the public at large that the [selfadministered] Courts ensure real transparency and accountability for their administration decisions and actions'. 
control by the executive government. ${ }^{209}$ A key feature of quality management systems is that they can give the courts a suite of transparent organisational tools to assist them to define their own concepts of organisational excellence and the means by which they can achieve those goals. ${ }^{210}$ According to Gething, the organisations that use quality management systems must also commit to systematically measuring, recording, improving, learning and changing their work practices, in order to meet and expand their own goals of organisational excellence. ${ }^{211}$ Importantly, the ongoing process of organisational self-assessment takes place across many different areas of court operations, including the financial area, the work processes area, the learning area and the customer area. ${ }^{212}$

A growing number of jurisdictions have successfully adopted quality management systems for use in the courts in recent years, including the US, Singapore, Finland and the Netherlands. ${ }^{213}$ Victoria can also be added to that list, following the recent introduction of the International Framework for Court Excellence ('IFCE') in the Magistrates', County and Supreme Courts. ${ }^{214}$ According to Vallance, the IFCE framework covers the so-called 'Seven Areas for Court Excellence', including 'court management and leadership', 'court planning and policies', 'court resources (human, material and financial)', 'court proceedings and processes', 'client needs and satisfaction', 'affordable and accessible court services' and 'public trust and confidence'. ${ }^{215}$ The framework is used in conjunction with the traditional indicators of court performance, such as case clearance rates, pending cases backlogs and numbers of case initiations and finalisations. ${ }^{216}$ According to the Chief Justice of Victoria, Marilyn Warren, the adoption of the quality management system has many inherent benefits for the courts, because it can be used to demonstrate how the courts are performing at any particular point in time, thus providing a more persuasive basis for funding

209 Langbroek, 'Quality Management and Autonomy', above n 55, 6-7.

210 Michael Gething, 'Assessing the Work of a Court: Performance Indicators and Quality' in Australian Courts: Serving Democracy and its Publics (Australasian Institute of Judicial Administration, 2013) 325, $333-4$.

211 Ibid.

212 Pim Albers, 'Performance Indicators and Evaluation for Judges and Courts' (Paper presented at the Anticorruption Seminar for the Russian Judges, Moscow, Russia, 24-25 May 2007) <http://www.coe.int/ t/dghl/cooperation/cepej/events/onenparle/MoscowPA250507_en.pdf> 11.

213 See, eg, National Center for State Courts, 'The International Framework for Court Excellence' (Report, International Consortium for Court Excellence, $2^{\text {nd }} \mathrm{ed}$, March 2013) 1; Quality Project of the Courts in the Jurisdiction of the Court of Appeal of Rovaniemi of Finland, 'Evaluation of the Quality of Adjudication in Courts of Law: Principles and Proposed Quality Benchmarks' (Report, March 2006); Netherlands Council for the Judiciary, 'Quality of the Judicial System in the Netherlands' (Report, March 2008).

214 Supreme Court of Victoria, Court Performance (15 February 2017) <http://www.supremecourt.vic. gov.au/home/about+the+court/court+performance/>.

215 Mike Vallence, 'Implementing the IFCE as a "Holistic" Means for Achieving Excellence: A Case Study of the Early Stages of Implementing the IFCE in the Supreme Court of Victoria' (Report, Supreme Court of Victoria, February 2013) 2. See also National Center for State Courts, 'Thinking of Implementing the International Framework for Court Excellence?' (Report, International Consortium for Court Excellence, $2^{\text {nd }}$ ed, March 2013) 3.

216 Vallence, above n 215, 13. 
submissions to the government and the treasury. ${ }^{217}$ Other benefits of the system include better 'identification of strategic priorities', improved 'cohesion between judiciary and administration' and a 'heightened sense of the courts' independence'. ${ }^{218}$

\section{Clearly Defined Administrative Powers, Rules and Rights of Access to Information}

Another area in which judicial councils and courts can emulate organisational best practices from the business sector is through the introduction of transparent internal administrative 'constitutions' and rules with clearly defined duties and responsibilities of judges and court staff. For example, in many US and European jurisdictions there are comprehensive rules that formally regulate the functions and powers of the chief and administrative judges, court administration, court committees, judicial scheduling teams and so on. ${ }^{219}$ Notably, the Judicial Administration Rules in California also provide detailed rules that govern the proceedings of the Judicial Council itself, including the basic rule that the business meetings of the Council are open to the public, subject to a few exceptions. ${ }^{220}$

The courts legislation in the Netherlands similarly prescribes the judicial administrative duties and responsibilities in some detail, while also imposing on the court management additional administrative requirements that must be addressed in separate court management 'regulations'. ${ }^{221}$ According to Article 23 of the Judiciary (Organisation) Act, the court management board is responsible for the budgeting, planning and control cycle, as well as the overall functioning of the courts, including personnel matters, organisational procedure and information and management systems. ${ }^{222}$ The court regulations must separately detail the internal management procedures of the management board, including those relating to decision-making, division of responsibilities, organisational structure, complaints procedure, delegation of duties, replacement of members in the event of illness and the jurisdictional allocation of cases between the court divisions. ${ }^{223}$

The principle of internal organisational transparency also has strong roots in the Scandinavian judicial systems. For example, according to Levin, freedom of information laws in Sweden give members of the public and the media

217 Chief Justice Marilyn Warren, 'Pursuit of Excellence and Innovation: Challenges for Implementation' (Speech delivered at the Australasian Institute of Judicial Administration Annual Conference 2013 - 'The Pursuit of Excellence and Innovation in Courts and Tribunals', Auckland, New Zealand, 7-9 March 2013) <http://www.aija.org.au/Asia\%20Pacific\%202013/Presentations/Warren\%20PPT.pdf> 6.

218 Ibid

219 National Center for State Courts, above n 96, 2. See generally, Tin Bunjevac, 'The Corporate Transformation of the Courts: Towards a Judicial Board of Executive Directors' (2016) 25 Journal of Judicial Administration 197.

220 See Judicial Council of California, California Rules of Court Title 10: Judicial Administration Rules (at 1 January 2016) r $10.6<\mathrm{http} / /$ www.courts.ca.gov/cms/rules/index.cfm?title=ten>.

221 Judiciary (Organisation) Act 1827 (Netherlands) art 19.

222 Judiciary (Organisation) Act 1827 (Netherlands) art 23.

223 Judiciary (Organisation) Act 1827 (Netherlands) art 19. 
extraordinary rights of access to all documents, materials and correspondence that are used by SNCA in its decision-making processes. ${ }^{224}$ Secondly, the institution of the Parliamentary Ombudsman is authorised to investigate the conduct of independent agencies, propose legislative solutions to Parliament, and even initiate prosecutions in serious cases. ${ }^{225}$ Lastly, it was noted earlier that the internal organisational transparency in the Nordic countries is also furthered by the diverse composition of the board of the judicial council.

\section{Transparent Budgeting, Workload Measurement and Fiscal Management}

The final, and perhaps the most contentious, aspect in the relationship between the judiciary and the executive government considered in this article concerns the issue of court budgeting and the accompanying criteria for the distribution of funds to the courts. In the executive system, there was an expectation that the courts should deliver a certain number of cases mandated by the Treasury, even though they had insufficient operational and fiscal authority over the resources needed to achieve those outputs. ${ }^{226}$ According to Alford, Gustavson and Williams, this resulted in an anomalous situation whereby executive officials who were located outside the courts were effectively in charge of the allocation of funds within the courts. ${ }^{227}$

The transfer of fiscal responsibility to the judicial council partially resolves this anomaly, to the extent that the executive government and parliament have agreed to provide the courts with a global budget, while devolving the responsibility for the allocation of the funds to the judicial council. However, even in this situation the problem remains in specifying the appropriate output targets and attaching a monetary value to them, because the services provided by the courts cannot be easily quantified. For example, as Alford, Gustavson and Williams pointed out, the agreed 'outputs' are typically expressed in a global number of cases to be resolved over a period of time, which does not take into account the complexity and resources involved in processing those cases, such as the cost of court infrastructure or the number of separate hearings and appeals that may form part of each dispute. ${ }^{228}$ The problem of specifying the appropriate outputs is further compounded by the fact that the Australian courts have not yet developed sophisticated systems for workload measurement, while most judges and court administrators appear to be 'relatively unfamiliar' with recent advances in this area in comparable jurisdictions. ${ }^{229}$ Kathy Mack, Anne Wallace and

224 See generally, Paul T Levin, 'The Swedish Model of Public Administration: Separation of Powers -The Swedish Style' (2009) 4(1) Journal of Administration \& Governance 38, 39-40.

225 Ibid 41.

226 Alford, Gustavson and Williams, above n 24, 43.

227 Ibid 42-3. They explain that the resulting fiscal discrepancy between 'responsibility' and 'controllability' is viewed unfavourably in accounting theory, because it has the potential to cause 'severe dysfunction within the organisation'.

228 Ibid 45.

229 Kathy Mack, Anne Wallace and Sharyn Roach Anleu, Judicial Workload: Time, Tasks and Work Organisation (Australasian Institute of Judicial Administration, 2012) 166, 168. It is pointed out that the Family Court of Australia had previously developed a system of workload benchmarking for judges and staff but has discontinued its use: see O'Ryan and Lansdell, above n 168. 
Sharyn Roach Anleu recently conducted a series of longitudinal empirical studies of courts across Australia and found that there was '[1]imited availability or use of workload measures', coupled with '[r]eliance on somewhat unwieldy manual systems and implicit institutional knowledge'. ${ }^{230}$ They noted that even where the statistics about judicial caseloads had been collected on a systematic basis, they did not take into account the differences in weight between different types of cases. ${ }^{231}$ Mack, Wallace and Anleu concluded that the 'existing systems appear to be largely inadequate' for the purposes of measuring and allocating workloads in the courts. ${ }^{232}$

Mack, Wallace and Anleu also pointed out that a number of jurisdictions in the US, Canada and Europe have successfully introduced sophisticated systems for measuring weighted caseloads. ${ }^{233}$ They explain that a weighted caseload measurement system has many practical benefits for the courts, because it allows for more accurate estimation of the judicial and administrative staff workloads, which can be used to justify requests for additional resources from the government. ${ }^{234}$ According to a National Center for State Courts report, in the US a weighted caseload system allows courts to determine the amount of 'judge time' and 'administrative time' that is needed to hear a specific type of case, as well as the amount of time a typical judge has available for hearing cases during a typical year. ${ }^{235}$ This allows the courts to develop reasonably accurate projections of 'judgeship' and 'support staff' needs to process the anticipated annual caseloads. ${ }^{236}$

The accuracy of weighted caseload systems largely depends on the quality of data obtained from empirical studies, expert user estimations and historical analyses of court files. As a result, the process can be administratively burdensome and requires regular follow-up studies to ensure that the benchmarked time standards and resource estimations remain accurate. In Germany, the introduction of the Pebbsy workload measurement system in 2002 was based on an empirical court study involving almost 2000 judges and prosecutors in more than 40 courts across seven federal states. ${ }^{237}$ The study came up with average processing times for several different types of cases, expressed in minutes, which were then used to calculate the annual workloads for courts in

230 Mack, Wallace and Anleu, above n 229, 7.

231 Ibid 164. The authors refer to the collection of data which is regularly published by the Productivity Commission and the Australian Bureau of Statistics: see Steering Committee for the Review of Government Service Provision, 'Report on Government Services: Court Administration' (Productivity Commission, January 2011); Australian Bureau of Statistics, 'Criminal Courts, Australia, 2009-10' (Publication No 4513.0, 27 January 2011).

232 Mack, Wallace and Anleu, above n 229, 166.

233 Ibid

234 Ibid 167-8.

235 Victor E Flango and Brian J Ostrom, 'Assessing the Need for Judges and Court Support Staff' (Report, National Center for State Courts, 1996) 25, 39.

236 Ibid 41, 59-60.

237 Burkhard Hess, 'Practical Ways of Combating Delays in the Justice System, Excessive Workloads of Judges and Case Backlogs: German Report' (Paper presented at CEPEJ Follow-Up Seminar -'Practical Ways of Combating Delays in the Justice System, Excessive Workloads of Judges and Case Backlogs', Ljubljana, Slovenia, 27-28 September 2005) 23. 
different states. According to Hess, the quality of the data is gradually improving, due to ongoing modernisation of ICT infrastructure that allows more comprehensive data collection of business processes and activities in the court system..$^{238}$

The weighted workload measurement system that was introduced in the Netherlands is especially noteworthy in the present context, because the Dutch Judicial Council itself had been the driving force behind the development and implementation of the system. ${ }^{239}$ The 'Lamicie' workload model is based on periodic time studies conducted by a commission of judges that calculate the average processing times for 49 different types of cases, which are expressed in the number of minutes of judge and staff time required to process each type of case. ${ }^{240}$ Remarkably, the workload model is used in the annual negotiations between the Judicial Council and government to determine the judiciary's budget appropriations, based on a fixed cost price assigned to each type of case by regulations. ${ }^{241}$

The examples from foreign jurisdictions should be treated with a degree of caution, however. According to Mack, Wallace and Anleu, even though the weighted caseload systems are useful in measuring case complexity, they still cannot measure the quality of outcomes, or the experiences of litigants. ${ }^{242}$ In fact, it has been pointed out that the introduction of output funding and 'casemix' systems such as Lamicie could potentially have negative consequences on the quality of justice if the courts get carried away in emphasising productivity over content quality. ${ }^{243}$ Alford, Gustavson and Williams explain that similar concerns had arisen when a casemix system was initially introduced to improve efficiency in the public health system. ${ }^{244}$ Hospitals had an incentive to shorten patient stays, because they were funded according to the specific treatment types, rather than the number of days that patients were actually being treated. In addition, the

238 Ibid.

239 Netherlands Council for the Judiciary, 'The Financing System of the Netherlands Judiciary' (Report) $<$ https://www.rechtspraak.nl/SiteCollectionDocuments/The-Financing-System-of-the-NetherlandsJudiciary.pdf $>$. See also the Court Sector (Funding) Decree 2005 (Netherlands) arts 2-3.

240 Pim Albers, 'Reducing Delays: Recent Developments in the Netherlands' (Paper presented at CEPEJ Follow-Up Seminar - 'Practical Ways of Combating Delays in the Justice System, Excessive Workloads of Judges and Case Backlogs', Ljubljana, Slovenia, 27-28 September 2005) 11-13. See also Philip M Langbroek, 'Organization Development of the Dutch Judiciary, between Accountability and Judicial Independence' (2010) 2(2) International Journal for Court Administration 21, 28.

241 Langbroek, 'Organization Development of the Dutch Judiciary', above n 240, 28. According to Langbroek, the Council for the Judiciary receives the budget from the Ministry of Justice based on a simplified calculation of 11 broad case types across all courts, while the budget between the Council and the courts is actually based on 49 individual categories of cases.

242 Mack, Wallace and Anleu, above n 229, 170, 178.

243 Langbroek, 'Organization Development of the Dutch Judiciary', above n 240, 28. See also Mohr and Contini, 'Judicial Evaluation in Context', above n 65, 272-3. See also Nina L Holvast and Nienke Doornbos, 'Exit, Voice, and Loyalty within the Judiciary: Judges' Responses to New Managerialism in the Netherlands' (2015) 11(2) Utrecht Law Review 49. The authors pointed out that 'it is the focus on the new public management principles that is of particular concern to the judges, as many of these principles may conflict with their professional values': at Abstract <https:/www.utrechtlawreview.org/articles/ abstract/10.18352/ulr.317/>.

244 Alford, Gustavson and Williams, above n 24, 48. 
system encouraged hospitals to diagnose patients into categories of cases that attracted higher funding. ${ }^{245}$

Despite the caveats, Alford, Gustavson and Williams considered the casemix system to be generally suitable for the courts and did not regard the methodology as an insurmountable problem from a technical point of view. ${ }^{246}$ They also pointed out that some of the negative tendencies of the casemix system experienced by hospitals would likely be offset in the courts due to the adversarial system of litigation. ${ }^{247}$ This is because judges have relatively limited capacity to influence the prosecution and defence in criminal cases or lawyers in civil litigation. ${ }^{248}$ In the Netherlands, the negative tendencies of the Lamicie model have been counterbalanced by a quality management system called RechtspraaQ, which imposes a series of qualitative measures and standards to ensure that the courts maintain their focus on delivering high quality legal outcomes. ${ }^{249}$ The measures and instruments developed for these purposes include detailed 'quality regulations', court-wide positioning and peer review studies, mandatory requirements for periodic second-reading of judgments, guaranteed times for judicial education, client evaluation surveys, staff satisfaction surveys, judicial complaints procedures, visitations and audits, as well as a judicial performance appraisal system. ${ }^{250}$ All of these measures show that it is not impossible to formalise the fiscal relationship between the judiciary and the executive in a transparent and accountable manner, while also maintaining focus on the quality of justice.

\section{CONCLUSION}

The principal aim of this article has been to critically analyse recent structural reforms of court governance and to identify factors leading to the emergence of judicial councils in many jurisdictions around the world. The need for structural organisational change had arisen because the traditional responses to the problems of delay, cost and complexity in litigation were no longer capable of responding to the contemporary challenges impacting the courts. The analysis shows that judicial control of court administration is key to any structural reform of the court system, since no major organisational improvements can be contemplated in the courts without more active judicial participation and leadership in that process. However, the analysis also makes it clear that judgecontrolled systems of court administration have problems of their own, because most judges have little time, management experience or inclination to work as part of a large court bureaucracy. Indeed, the process of designing and

245 Ibid.

246 Ibid 47-8. They point out that the case types can be fine-tuned to provide flexible 'outliers' for unexpectedly short or lengthy cases.

247 Ibid.

248 Ibid.

249 Netherlands Council for the Judiciary, above n 213.

250 Ibid 5-10. 
implementing structural organisational change in the judicial environment can be a gargantuan task, because it involves detailed consideration and the interplay of key threshold concepts of court administration, such as the independence of the judiciary, administrative transparency and accountability, organisational efficiency and accessibility, as well as the quality of justice. Above all, the transfer of responsibility for court administration to the judiciary requires a thorough reassessment of the judicial role in court administration, because it is difficult to imagine organisational improvements in any large organisation without a robust system of administrative accountability. International experiences strongly suggest that greater internal administrative transparency and administrative 'corporatisation' of the judiciary is essential at all levels of the judicial organisation in order to improve court performance, enhance the social legitimacy of the courts and reinforce judicial independence.

The recent proliferation of the 'court services model' of judicial councils in many developed countries represents an attractive attempt to address the traditional challenges of judge-controlled systems of court administration, because these institutions are vested with remarkably broad powers to act as a supporting and developmental engine for the courts, while also safeguarding their independence from the executive government. The research shows that a judicial council should ideally be governed by a small board of administrative judges and non-judicial experts, who would be appointed for a fixed term based on merit. At the level of the courts, the experiences from Europe, the US and the Australian federal courts show that the system of integrated management has many inherent benefits for the courts, because it can greatly improve their efficiency, by promoting more active judicial involvement in court administration and by furthering their self-responsibility as autonomous organisations.

The executive government's role appears to be significantly diminished in this model, because the Minister no longer has day-to-day insight into the court system operations or any powers to manage the courts, except, perhaps, to intervene in cases of well-defined emergency. To compensate for the lack of ministerial insight and involvement in court administration, the judicial council and the courts should develop new mechanisms of administrative and financial accountability that are transparent, verifiable and more customer-focused. 